\title{
The Results of the Project on Creation of Special Protection Zones in Pine Forest Nature Reserves of the Altai Kray Based on Data from the Long-term Monitoring of Raptors' Nesting Sites, Russia РЕЗУЛЬТАТЫ ПРОЕКТА ПО ВЫДЕЛЕНИЮ ЗОН ОСОБОЙ ОХРАНЫ В БОРОВЫХ ЗАКАЗНИКАХ АЛТАЙСКОГО КРАЯ НА ОСНОВАНИИ ДАННЫХ МОНИТОРИНГА МЕСТ ГНЕЗДОВАНИЯ ПЕРНАТЫХ ХИЩНИКОВ, РОССИЯ
}

\author{
Karyakin I.V. (Center of Field Studies, N. Novgorod, Russia) \\ Nikolenko E.G. (Sibecocenter LLC, Berdsk, Novosibirsk region, Russia) \\ Карякин И.В. (Центр полевых исследований, Н.Новгород, Россия) \\ Николенко Э.Г. (ООО «Сибэкоцентр», Бердск, Новосибирская область, Россия)
}

\section{Контакт: \\ Игорь Карякин \\ Центр полевых \\ иссиедований \\ 603109, Россия \\ Нижний Новгорох \\ ул. Нижегородская, \\ 3-29 \\ тел.: +7831433 3847 \\ ikar_research@mail.ru}

Эльвира Николенко

ООО "Сибэкоцентр"

630090, Россия

Новосибирск, а/я 547

тел.: +79231501279

elvira_nikolenko@mail.ru

\section{Contact:}

Igor Karyakin

Center of Field Studies

Nizhegorodskaya str.,

3-29

Nizhniy Novgorod

Russia, 603109

tel.: +7831433 3847

ikar_research@mail.ru

Elvira Nikolenko

Sibecocenter LLC

P.O. Box 547,

Novosibirsk

Russia, 630090

tel.: +79231501279

elvira_nikolenko@mail.ru

\section{Резюме}

В статье приводится обзор состояния редких видов пернатых хишников, гнезАящихся в ленточных борах Аһтайского края. Показаны негативные тренды мяя ряла видов, в частности беркута (Aquila chrysaetos) и филина (Bubo bubo), по причине постоянно ведушихся рубок. На основании результатов многолетнего мониторинга хишных птиц разработаны критерии вылеления особо зашитных участков леса и зон особой охраны в боровых заказниках Алтайского края. По результатам исследований 2015 г. спроектированы зоны особой охраны мля Камсаиинского, Мамонтовского и Корниловсокго заказников. Во всех вышеперечисленных заказниках, а также в Завьяловском заказнике проведены инспекции, выявившие многочисленные нарушения природоохранного законодательства. По факту нарушений инициированы проверки соблюдения законодательства при эксплуатации лесов.

Киючевые слова: хищные птицы, пернатые хищники, степные боры, заказники, Алтайский край.

Поступияа в редакцию: 28.08.2015 г. Принята к публикации: 18.12.2015 г.

\section{Abstract}

This article provides the review of the condition of rare raptors' species, nesting in strip-shaped pine forests of the Altai Kray. It also reflects negative trends for some species including the Golden Eagle (Aquila chrysaetos) and the Eurasian Eagle Owl (Bubo Bubo) due to constant felling. Criteria of selection of special protection zones of forests and zones of special protection in nature reserves in the pine forests of the Altai Kray were designed according to the results of the long-term monitoring of raptors. According to researches of 2015 zones of special protection were designed for Kamsalinsky, Mamontovsky and Kornilovsky nature reserves. Inspections conducted in all mentioned nature reserves and in Zavyalovsky nature reserve showed numerous violations of environmental legislation. Thereafter checks on compliance with the legislation in forest exploitation were initiated.

Keywords: birds of prey, raptors, steppe pine-forest, protected areas, nature reserves, Altai Kray. Received: 28/08/2015. Accepted: 18/12/2015.

DOI: $10.19074 / 1814-8654-2015-31-75-102$

\section{Введение}

Проблема уничтожения мест гнездования редких видов в заказниках Алтайского края имеет миительную историю и уже многие годы озвучивается учёнными и обшественными деятелями (Смелянский, 2005; Николенко и Ар., 2012; 2013; Рыжков, 2013; Грибков, 2014; Николенко, 2014). Несмотря на то, что по российскому законодательству, действия, которые могут привести к гибели, сокрашению численности или нарушению среды обитания объектов животного мира, внесённых в Красную книгу РФ, не допускаются (ст. 24 Федерального закона "О животном мире" от 24.04.1995 № 52-Ф3, реА. от 13.07.2015), а нарушение этого требования наказывается значительными штра-
Monitoring of rare raptors' species populations in strip-shaped pine forests of the Altai Kray has been conducted since 2003.

The most dramatic is the situation with the Golden Eagle (Aquila crysaetos) in Altai pine forests. There were 6 known nesting sites until 2005 with total number estimated at 52-61 pairs, Golden Eagles were met regularly in all large swamp complexes in pine forests (Karyakin et al., 2005). The last case of the Golden Eagle nesting in stripshaped pine forest dates back to 2013 (fig. 3). Perennial nest of one of those eagles still remains in Kornilovsky reserve, which was reserved by at least one Golden Eagle in 2014, but in 2015 it was occupied by a Greater Spotted Eagle (Aquila clanga), and Golden Eagles weren't noticed in the 
Вырубка на гнезцовом участке большого подорлика (Aquila clanga). Фото И. Карякина.

Logging on the breeding territory of the Greater Spotted Eagle (Aquila clanga). Photo by I. Karyakin.

фами (ст. 8.35 КоАП РФ) и возмешением нанесённого вреда (Методика..., 2008), в Алтайском крае ежегодно уничтожаются гнёзаа редких виАов хишных птиц. Масштабы этого уничтожения не имеют анамогов нигде в России, что связано как с уникаиьными природными условиями алтайских боров, так и с беспрецедентной коррумпированностью властей всех уровней в Аитайском крае. В частности, только за 12-летний период 2000-2011 гг. в алтайских борах, в том числе и на особо охраняемых природных территориях (ООПТ), рубками было уничтожено 22 гнездовых участка таких редких видов, как беркут (Aquila chrysaetos), орёл-могильник (Aquila heliaca), большой подорлик (Aquila clanga), орлан-белохвост (Haliaeetus albicilla), бамобан (Falco cherrug), фимин (Bubo bubo) (Николенко и Ар., 2012). Практически по всем фактам уничтожения гнёзд редких видов были проведены прокурорские и ведомственные проверки, признавшие сракт нарушения прироАоохранного законодательства, однако лесопользователи, Аопустившие нарушения, ушли от ответственности при содействии или банальном попустительстве госорганов, призванных контролировать соблюдение законов в ссере охраны природы и объектов животного мира. После 2004 г. интенсивность рубок по всей территории ленточных боров многократно возросла, и кишь заказники испытывали несколько меньший пресс рубок, чем соседние

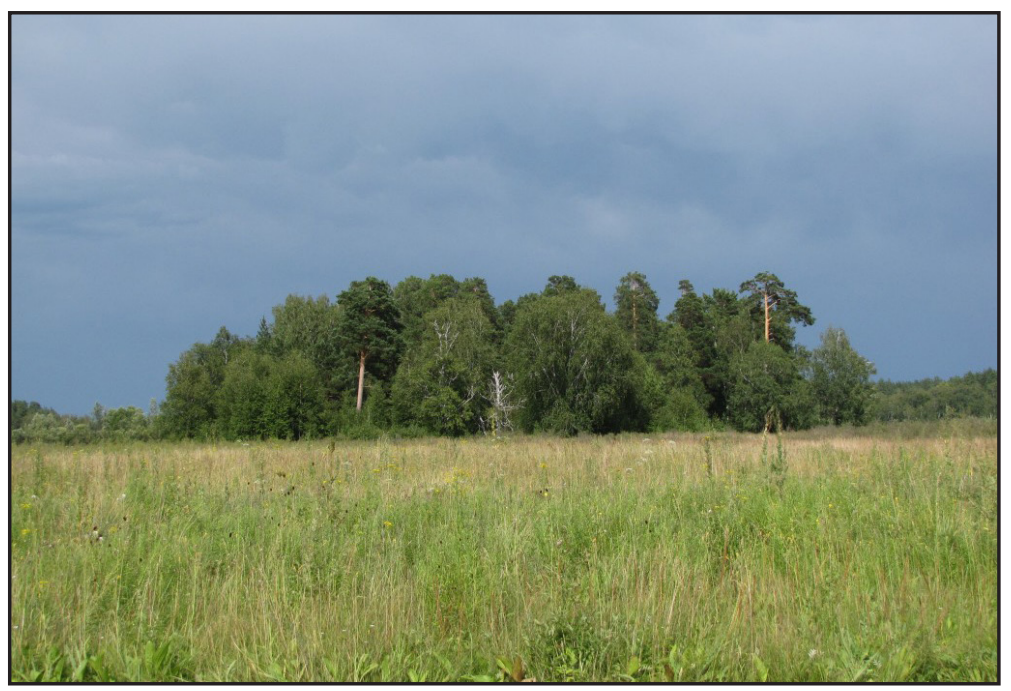

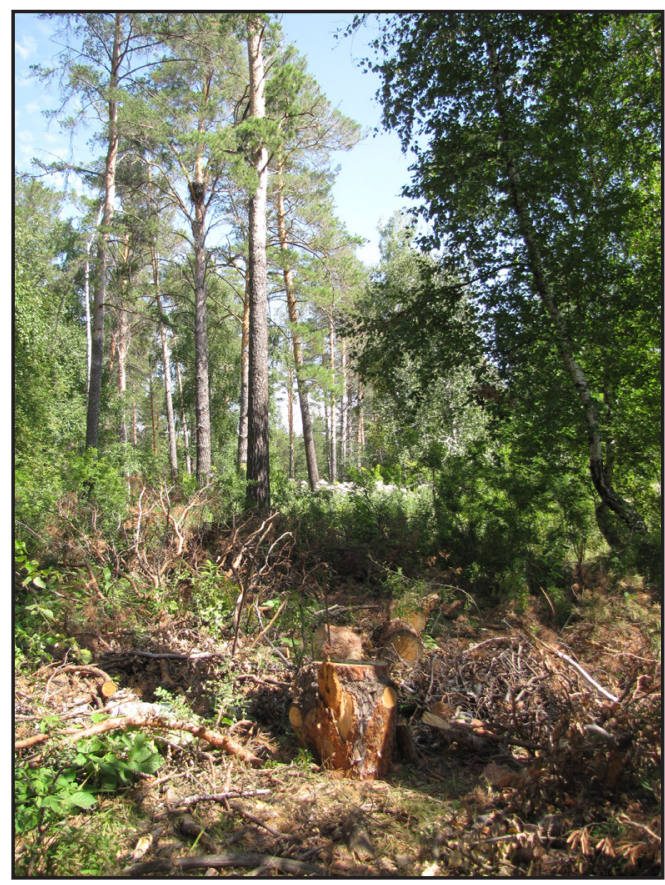

reserve. Main reasons, which supposedly lead to a rapid decrease in the Golden Eagle's number in pine forests, are expanding areas of deforestation, increasing stress and poaching, undermining of the food reserve (Lepus sp., Tetraonidae). It's worth mentioning that along with rapid extinction of the Golden Eagle nesting in pine forests of the left bank of the Ob river, population of the Golden Eagle in the foothills of Altai consistently grows in number since 2005 (Karyakin et al., 2010).

With the collapse of the pine forest population of the Golden Eagle a rapid increase in number of the White-Tailed Eagle (Haliaeetus albicilla) started on this territory. If until 2005 in strip-shaped pine forests were known only 16 nesting sites of the WhiteTailed Eagle connected with large lakes, and its number estimated at $60-70$ pairs (Karyakin et al., 2005), then at the moment the species begins to nest on smaller lakes and even along the swamps with system of small lakes. There were 48 nesting sites found in belt pine forests in 2015 (fig. 4) and the number is estimated at 120-140 nesting pairs.

The number of the Greater Spotted Eagle in strip-shaped pine forests of the

Лесной остров среди болота в Касмалинском заказнике. Фото И. Карякина.

Forested island among the marsh in the Kasmalinsky Nature Reserve. Photo by I. Karyakin. 
участки боров. ОАнако, несмотря на сопротивление обшественности, освоение заказников лесозаготовителями постепенно нарастало. В 2013 г. руководством края лесозаготовителям по сути был выдан картбланш на вырубку лесов на ООПТ: постановлениями ААминистрации Алтайского края № 404 от 26.07.2013 г. и № 450 от 16.08.2013 г. в положения о заказниках были внесены изменения, разрешаюшие заготовку Аревесины. Крупнейшим лесозаготовителем на этих территориях является лесной холдинг "Алтайлес", уже неоднократно попадавший в коррупционные скандаиы. Очевидно, что указанные выше постановления также имели "коррупционную составляюшую" и облегчами хомиингу освоение лесов на ООПТ. Противостояние обшественности, лесозаготовителей и коррумпированной власти фактически Аошло $\Delta$ о "последней черты", в результате чего власть вынуждена была пойти на компромисс. УАалось Аоговориться о вылелении хотя бы на территории ООПТ края, в частности в заказниках, в местах обитания редких видов животных и произрастания растений, зон особой охраны, в которых искиючаются все виды рубок, кроме санитарных.
Altai Kray stays more or less stable, despite the barbaric deforestation and regular nests destruction. At the moment 135 nesting sites of the Greater Spotted Eagle are known on the left bank of the river $\mathrm{Ob}$ (fig. 5), and its number estimates at 310320 pairs, more than a half of which nest in pine forests.

The Imperial Eagle (Aquila heliaca) is the second in number after the Greater Spotted Eagle in strip-shaped pine forests of the Altai Kray, pine forest population of which is relatively stable. In 2004 there were 89 known nesting sites of the Imperial Eagle, and its number was estimated at 125-130 nesting pairs (Vazhov, 2010). Between 2005 and 2010 about 40 nesting sites were damaged as the result of felling and forest fires. A part was in area of the long-term Red-Cheeked Ground Squirrel's (Spermophilus erythrogenys) number depression, as the result during those years reallocation of nesting eagles on margins of pine forest was observed, but the total number decreased insignificantly (if at all) (fig. 6). Now 80-85 breeding territories remain active in pine forests and the number is still estimated at 120-130 nesting pairs.

Another species, the number of which

На территории Аитайского края функционируют 93 ООПТ краевого уровня (37 государственных природных заказников, 55 памятников природы и один природный парк) и 1 - федераиьного (ФГБУ Государственный природный заповедник "Тигире́кский»). Плошахь ООПТ Аитайского края - 776,7 тыс. га., что составляет ^ишь 4,62 \% пиошаци края ${ }^{65}$.

In the Altai Kray there is 93 regional protected areas (37 nature reserves, 55 nature sites and 1 nature park) and 1 federal protected area (State Nature Reserve "Tigireksky"). The area of PAs of the Altai Kray -776.7 thousand hectares (only $4.62 \%$ of total area of Altai Kray).

Ао 2014 г. пилотные работы по проектированию зон особой охраны проведены на территории Панкрушихинского, Завьяловского, Егорьевского и Волчихинского заказников, при этом мия территории Панкрушихинского заказника зоны особой охраны закреплены в новом Положении о заказнике.

В 2015 г. работа по проектированию зон особой охраны на основе Аанных о местах гнездования хишных птиц начата в Касмалинском, Мамонтовском и Корниловском заказниках, по результатам которой и подготовлена Аанная статья.

\section{Методика полевых исследований}

Работа по обследованию заказников Алтайского края проводилась с 19 июля dramatically decreased in strip-shaped pine forests of the Altai Kray, along with that of the Golden Eagle, is the Saker Falcon (Falco cherrug). But the reasons defining its disappearance are somewhat different. There's no doubt that the Saker Falcon was suffering from deforestation as nest constructions of eagles which the Saker Falcon occupied for nesting were destroyed every year in small numbers. However, its disappearance was due to illegal trapping for falconry purposes. In strip-shaped pine forests the nesting group of $60-80$ pairs still remained until 2006, where only in 200332 nesting sites of falcons localized (Karyakin et al., 2005). In 2008-2010 there were 8 breeding territories checked, 3 of which were successful, in 2011-2013 - 11, two of which were suc-

\footnotetext{
65 http://www.altairegion22.ru/region_news/v-techenie-2015-goda-v-altaiskom-krae-budet-sozdano-7-novyh-osobo-ohranyaemyhprirodnyh-territorii_458606.html
} 
Pис. 1. Маршрут экспедиции по Алтайскому краю.

Fig. 1. The route of the expedition in the Altai Kray.

Рис. 2. Боровые заказники Алтайского края, в которых велись мониторинговые исследования хишных птиц в 2015 г.

Fig. 2. Monitoring of raptors was carried out in the nature reserves in the steppe forests of the Altai Kray in 2015.

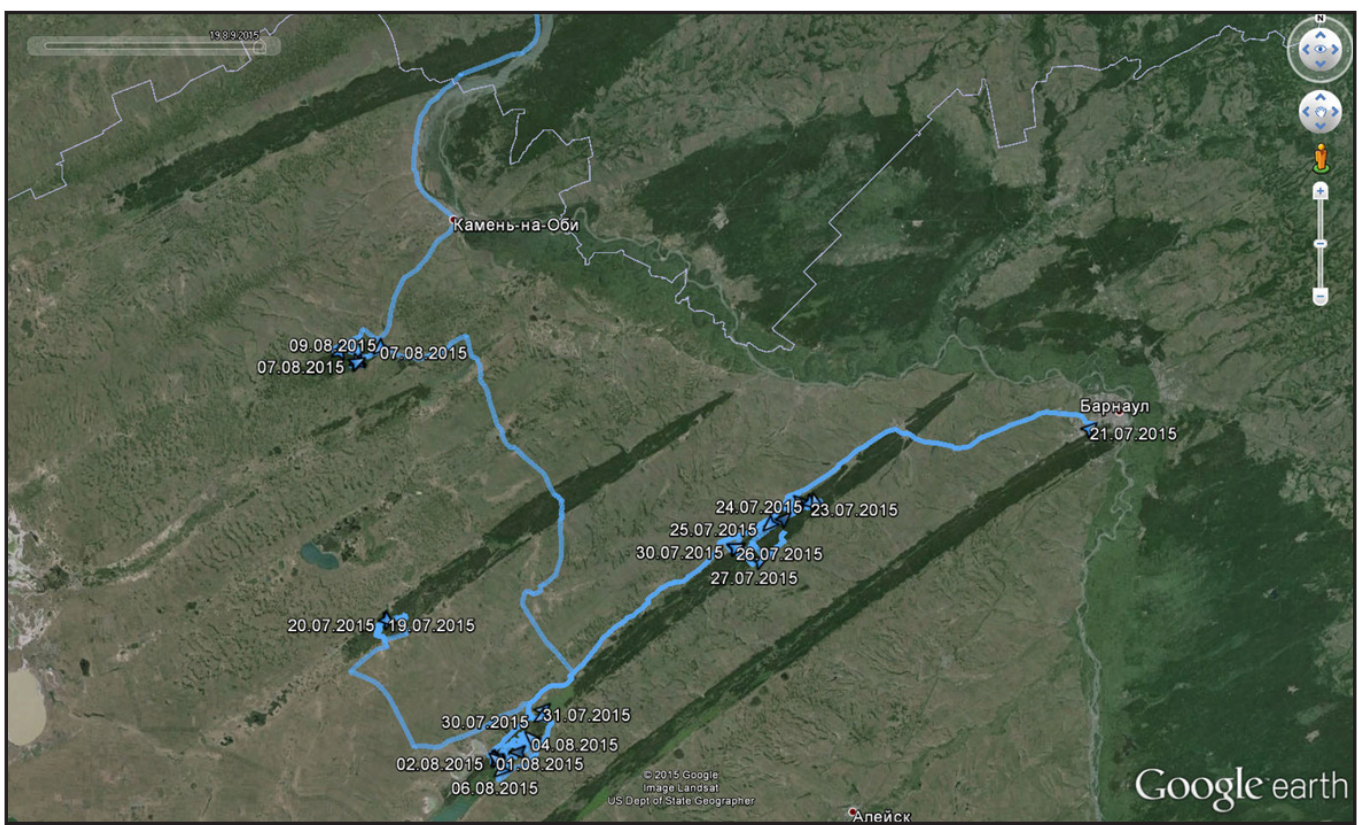

по 9 августа 2015 г. Автомаршрут экспедиции по Алтайскому краю составия 1442 км (рис. 1), протяжённость пеших маршрутов, преимушественно по территории заказников, - 96 км. Аостаточно хорошо были обследованы Касмаминский и Мамонтовский заказники (рис. 2), в Корниловском заказнике обследована боровая часть с упором на северную опушку, которая в предылушие годы осматривалась достаточно поверхностно. В Аополнении к основному плану полевых работ в Завьяловском заказнике (рис. 2) проведён мониторинг гнездовых участков хишных птиц и инспектирование зоны особой охраны, спроектированной в 2012 г.

Основной задачей полевых исследований являлся поиск гнёзА хишных птиц, в первую очередь редких видов, занесённых в Красные книги РФ и Алтайского края. Аия этого использоваяи стандартный

cessful. In 2014 out of 21 breeding territories checked only one was occupied (and it was successful at the moment) (fig. 7). Thus, the decrease of the pine forest population's number was at $95 \%$ (Karyakin et al., 2014). The current number of the Saker Falcon in pine forests is estimated at 3-5 pairs, remained mainly on Russia-Kazakhstan border.

The Eagle Owl (Bubo bubo) is a typical nesting raptor of strip-shaped pine forests, first of all suffering from deforestation and the depletion of food resource including hares and grouses, which are vital in winter period. In the end of 2014 in Altai Kray were 167 breeding territories of the Eagle Owl found, including 110 breeding territories in strip-shaped pine forest on the left bank of the river Ob $(65,9 \%$ of total known breeding territories in Altai Kray) (fig. 8). From 2008 to 2014 the Eagle Owl stopped reproducing on 21 breeding territories, in-

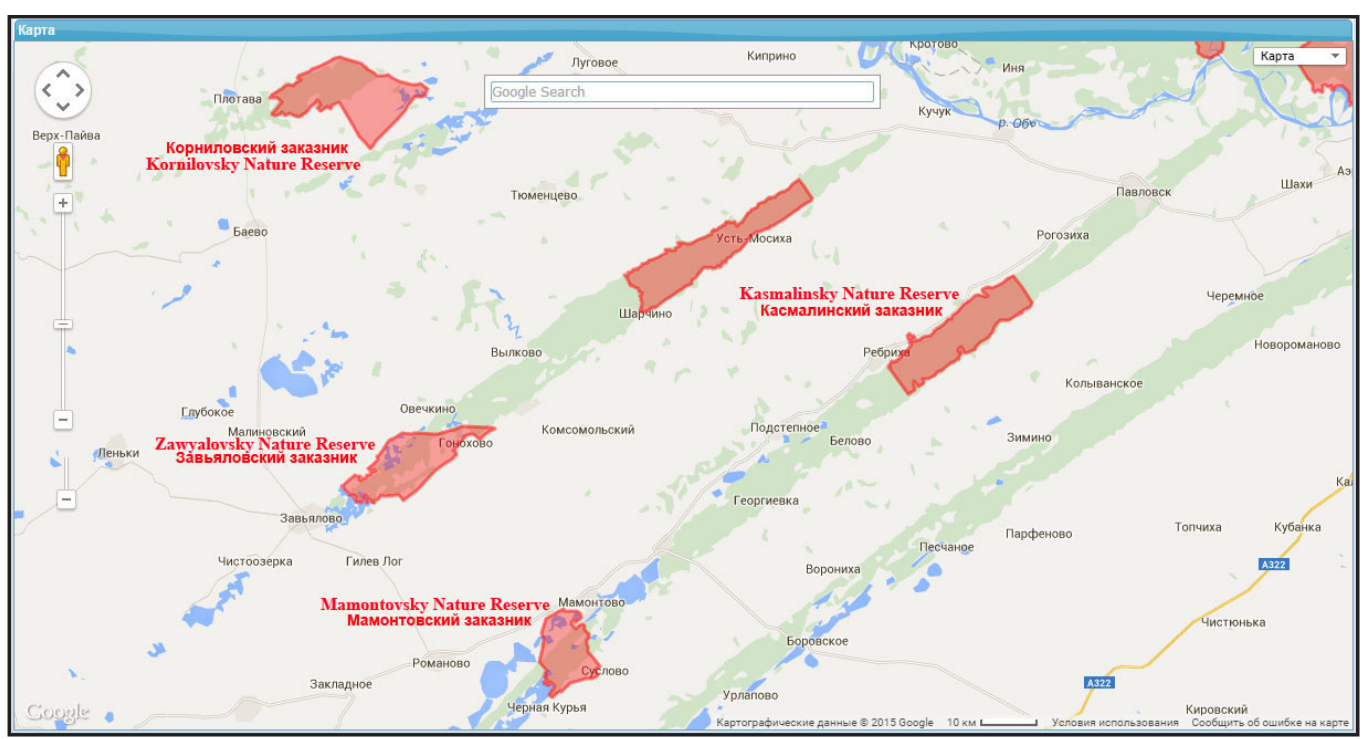


набор подходов по обследованию гнездопригодных местообитаний и мокамизации гнёзд, описанный в специамьной митературе (Карякин, 2004): проводили осмотр внешней боровой опушки на автомаршрутах с частыми остановками на точках, расположенных в пределах видимости, обследовали на пеших маршрутах лесную опушку по берегам открытых пространств и водоёмов, прочёсывами на пеших маршрутах участки высокоствольного леса, не просматриваюшиеся с открытых пространств, наблюдали за территорией на точках с широким обзором местности, преимушественно среди озёр и болот. Аия наблюдения за местностью использовами бинокии $10 \times 50,12 \times 50$. В ряле случаев мяя локализации участков провоцироваии территориальных птиц на вокамизацию имитацией их видоспецифических криков голосом или путём воспроизведения фонограмм.

Аля всех точек встреч птиц и локамизации гнёзд определялись геограсические коорАинаты с помошью спутникового навигатора, данные вносились в раздел "Пернатые хишники Мира" Веб-ГИС "Фаунистика" ${ }^{6}$. Ал камеральной обработки Аанные экспортироваиись в виде шейп-фрайла ESRI в ArcView 3x, гАе и осушествлялся итоговый анализ распределения хишных птиц и проектирование зон особой охраны.

Обзор статуса реАких видов хищных птиц в ленточных борах Аитайского края

Мониторинг популяций редких видов хишных птиц в ленточных борах Алтайского края ведётся нами с 2003 г. Рял видов за эти годы подошёл к опасной черте, за которой следует вымирание, Аругие, наоборот, увеличивают численность.

Наиболее Араматично скиадывается ситуация с беркутом в аитайских борах. $\Delta$ o 2005 г. здесь было известно 6 гнездовых участков, а общая численность оценивалась в 52-61 пар, беркуты регулярно встречались во всех крупных болотных комплексах боровых массивов (Карякин и мр., 2005). К 2008 г. было выявлено ешё 3 гнездовых участка, но при этом 4 ранее

Молодой беркут (Aquila chrysaetos). Фото Е. Шнайдер.

Juvenile Golden Eagle (Aquila chrysaetos). Photo by E. Shnayder. cluding 20 in strip-shaped pine forests. 146 breeding territories remained occupied in 2014, including 90 in Altai pine forests (61.6\% out of all occupied sites in Altai Kray). Total decrease of the Eagle Owl's population in 2014 sustained $46 \%$ for 12 years, with the most massive losses in period after 2007 due to active felling in stripshaped pine forests (Vazhov, Rybalchenko, 2013; Karyakin, 2014).

During the observation of pine forest nature reserves in 2015 found over 250 birds (198 observations on 196 points) from 16 species of raptor: 13 species of birds of prey and 3 species of owls - the Eagle Owl, the Ural Owl (Strix uralensis) and the Eurasian Scops Owl (Otus scops) (table 1). In 2015 such rodent specialists as harriers (Circus sp.), the Long-Eared Owl (Asio otus) and the Short-Eared Owl (Asio flammeus) were practically out of observation, and the number of Common Buzzard (Buteo buteo) was low, which is directly connected with the depression of numbers of small rodents in the plain of the left bank of the Ob river. As the result of field researches 24 breeding territories of the Greater Spotted Eagle was observed, as well as 9 breeding territories of the Eagle Owl, 7 breeding territories of the White-Tailed Eagle, 2 breeding territories of the Imperial Eagle and one breeding territory of the Golden Eagle (table 1).

There were nests on half of 24 breeding territories of the Greater Spotted Eagle, which were visited during the expedition: 12 occupied (50\%), out of which 10 were inhabited $(83.33 \%$ out of occupied nests and $41.67 \%$ out of visited nests) with one nestling in each. The amount of nests abandoned because of felling was $20.83 \%$, which lies within the borders of annual rate for the last 8 years.

Out of 7 breeding territories of the White-

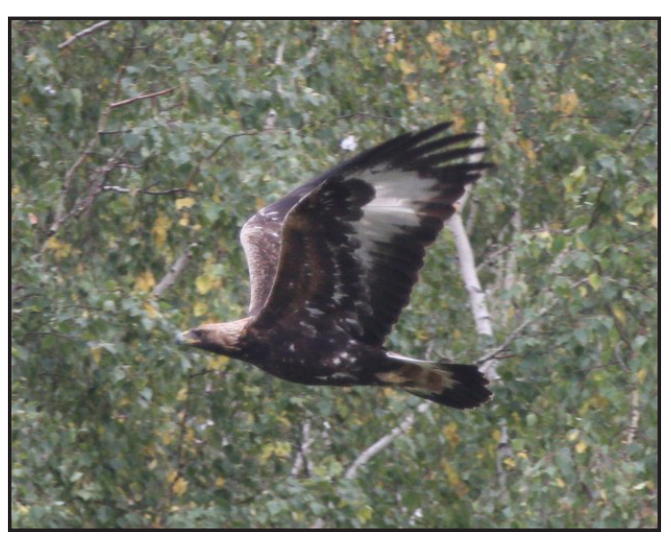


известных перестали сушествовать. Последний случай гнездования беркута в ленточных борах датируется 2013 годом (рис.

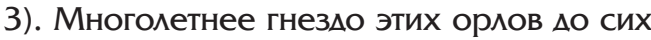
пор сохраняется в Корниловском заказнике, которое ешё в 2014 г. абонировалось как минимум одной взрослой птицей, но в 2015 г. его занял большой подорлик, а беркуты в заказнике не были встречены.

Основные причины, которые видятся в стремительном сокрашении численности беркута в борах - увеличивающиеся пиошаАи рубок, нарастающее беспокойство и браконьерство, подрыв кормовой базы. В борах стало меньше зайца (Lepus sp.) и боровой Аичи (Tetraonidae), и это хорошо заметно при сравнении регистраций этих животных в начале 2000-х гг. и после 2010 г. (при этом официаиьная информация по динамике численности зайцев и боровой Аичи ${ }^{67}$ не соответствует Аействительности и, скорее всего, фаиьсисицирована, как на этапе предоставления полевых Аанных егерями, так и на этапе обработки Аанных).

Стоит отметить, что на фоне стремительного исчезновения беркута на гнезАовании в борах Обского левобережья, популяция беркута в предгорьях Алтая методично увеличивается в численности с 2005 г. (Карякин и Ар., 2010)

С крушением боровой популяции беркута на Аанной территории начался стремительный рост численности орлана-белохвоста. Если Ао 2005 г. в ленточных борах было известно всего 16 гнездовых участков орланов-белохвостов, привязанных к крупным озёрам, а численность оценивалась в 60-70 пар (Карякин и мр., 2005), то

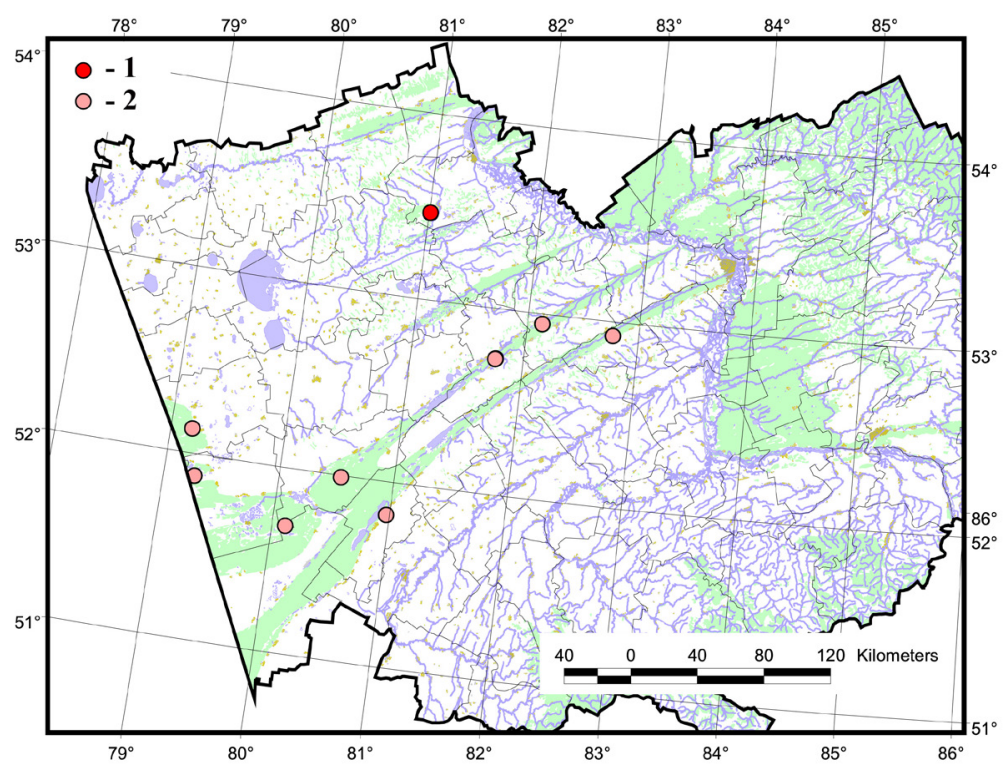

Tailed Eagle 3 nests were occupied, all three with the successful reproduction there were fledglings near the nests. In Mamontovsky nature reserve for the first time in strip-shaped pine forests a breeding territory of the White-Tailed Eagle was found, with two nesting constructions (living and old on withered pine) situated on the edge of pine forest at the distance from lakes and swamps. In this case, the White-Tailed Eagles occupied the site that had been occupied by the Imperial Eagle earlier, displacing the last from this part of the pine forest.

Out of 9 observed breeding territories of the Eagle Owl, occupied nests were found on 3 of them (33.3\%), 2 of which were successful $(66.67 \%$ out of total occupied nests and $22.22 \%$ out of visited breeding territories) - there was one fledgling vocalizing near each nest during night time. A bit less than half of the breeding territories (44.44\%) were empty because of the felling which was conducted close to the nests.

As it can be seen from the review of the condition of the rare raptors' species in strip-shaped pine forests in Altai Kray and the results of monitoring in 2015, the destruction of nests during felling is one of the most important reasons of the reduction of rare species' numbers.

Despite the fact that according to Russian legislation actions that lead to death, depletion of number or disturbing the habitat of wildlife listed in the Red Book of Russia, are not allowed (art. 24 of the Federal Law № 52 "On Wildlife" of 24.04.1995 № 52 FZ, ed. of 13.07.2015), and the violation of this law is punishable by fines (art. 8.35 of the Code of the Russian Federation on Administrative violations) and compensation of the harm caused (The Methodology..., 2008) in Altai Kray nests of the rare raptors' species are destroyed annually. The scale of destruction is unlike to any other in Russia, which is connected both with unique natural conditions of Altai pine forests and with unprecedented corruption of all levels of

Рис. 3. Распространение беркута (Aquila chrysaetos) в аитайских борах: 1 - гнездовые участки, занимавшиеся в 2010-2015 гг., 2 - гнездовые участки, занимавшиеся до 2010 г.

Fig. 3. Distribution of the Golden Eagle (Aquila chrysaetos) in the Altai pine-forests: 1 - breeding territories occupied in 2010-2015, 2 - breeding territories occupied before 2010.

${ }_{67}$ http://altaipriroda.ru/directions/oxot_xozjajstvo/uchyot_zhiv 
в настояшее время вид стаи гнездиться на небольших озёрах и Ааже вАоль болот с системой мелких озёр. К 2015 г. в ленточных борах выявлено 48 гнездовых участков (рис. 4), а численность оценивается в 120-140 гнездящихся пар.

С ростом численности орлана мы ожиАали, что он будет вытеснять подорликов с побережий озёр, однако $о$ сих пор такие случаи единичны, и в масштабах ленточных боров орлан и подорлик научились сосушествовать Аруг с Аругом. Орланы и подорлики успешно размножаются в гнёзАах, удалённых Аруг от мруга на расстояние менее 1 км.

Численность большого подорлика в ленточных борах Алтайского края остаётся более или менее стабильной, несмотря на варварские рубки и регулярное уничтожение гнёзд. В настояшее время в Обском левобережье известно 135 гнезАовых участков подорликов (рис. 5), а численность, как и в 2005 г., оценивается в 310-320 пар, более половины из которых гнездятся в борах.

Орёл-могильник - второй после подорлика по численности орёл ленточных боров Аһтайского края, боровая популяция которого относительно стабильна. К 2004 г. в ленточных борах было известно 89 гнездовых участков орлов-могильников, а численность оценивалась в 125-130 гнездящихся пар (Важов, 2010). В период между 2005 и 2010 гг. около 40 гнезАовых участков пострацало в результате рубок и пожаров, часть попало в зону затяжной депрессии численности красношёкого суслика (Spermophilus erythrogenys), в результате все эти годы наблюдалось регулярное перераспределение орлов на гнездовании

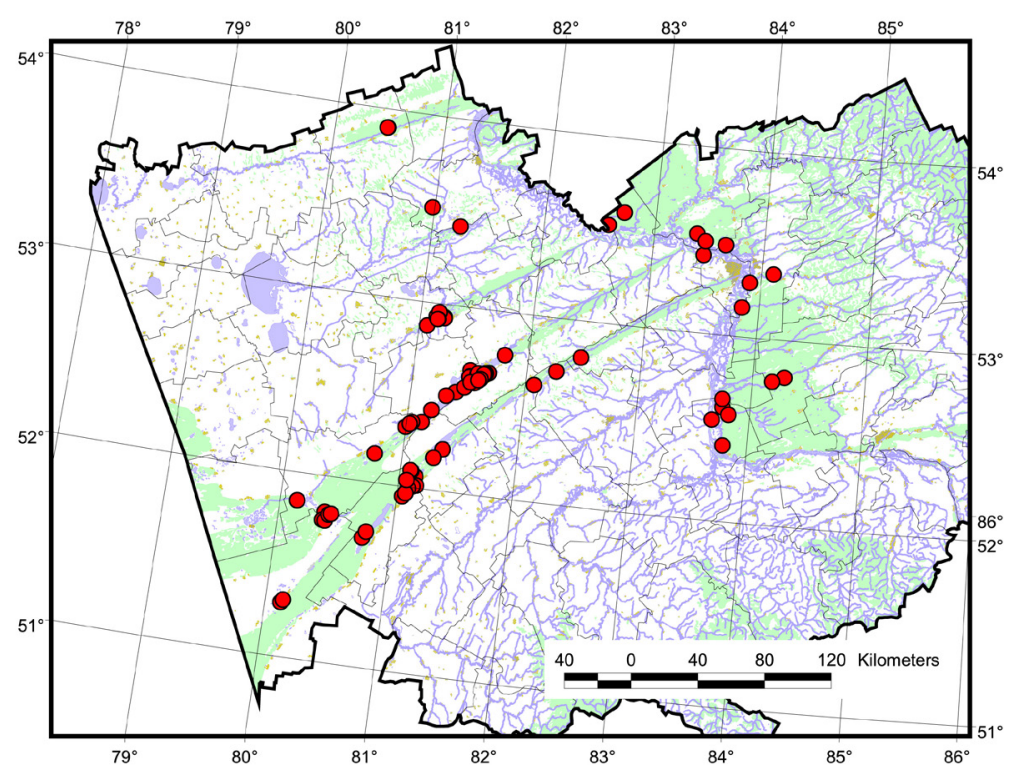

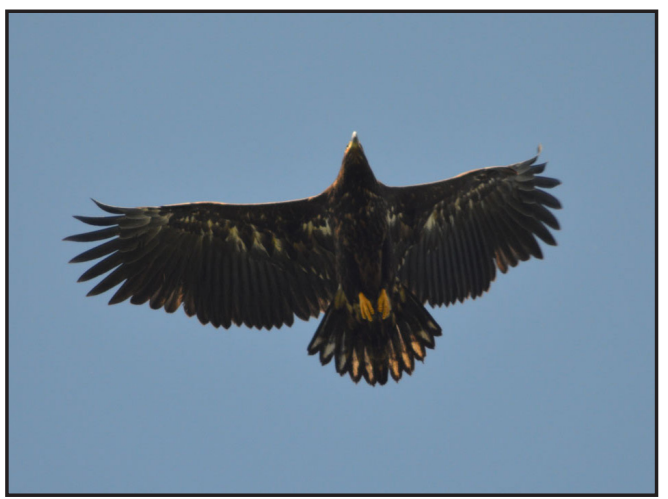

Молодой орлан-белохвост (Haliaeetus albicilla). Фото И. Карякина Juvenile White-Tailed Eagle (Haliaeetus albicilla). Photo by I. Karyakin.

authorities in Altai Kray. In particular, only over the period of 12 years in 2012 in Altai pine forests, including protected areas (PA), 22 breeding territories of such species as the Golden Eagle, the Imperial Eagle, the Greater Spotted Eagle, the White-Tailed Eagle, the Saker Falcon, the Eagle Owl were destroyed by felling (Nikolenko et al., 2012). Nearly all facts of nests' destruction were investigated during departmental and prosecutors' checks, which admitted the fact of violation of environmental legislation. However, forest users who allowed violations escaped responsibility with the help and allowance of state authorities, who are controlling the compliance with the laws in nature and wildlife conservation.

There's no doubt that it's impossible to top felling by taking nesting groups of avian predator in belt pine forests under territorial protection as PAs. This process will meet the strong lobby of the loggers affiliated with state authorities. Moreover, those nesting groups are concentrated in most of the pine forest, and even a clustertype PA of reasonable size will not cover even half of known breeding territories of rare species. In strip-shaped pine forests, the only way to reserve the breeding territories of raptors seems to be creation of special protection forest zones (SPFZ) on breeding territories of the rare raptors' species.

Рис. 4. Современное распространение орланабелохвоста (Haliaeetus albicilla) в алтайских борах: занятые гнездовые участки по состоянию на 2015 г.

Fig. 4. Modern distribution of the White-Tailed Eagle (Haliaeetus albicilla) in the Altai pine-forests: occupied breeding territories to 2015. 


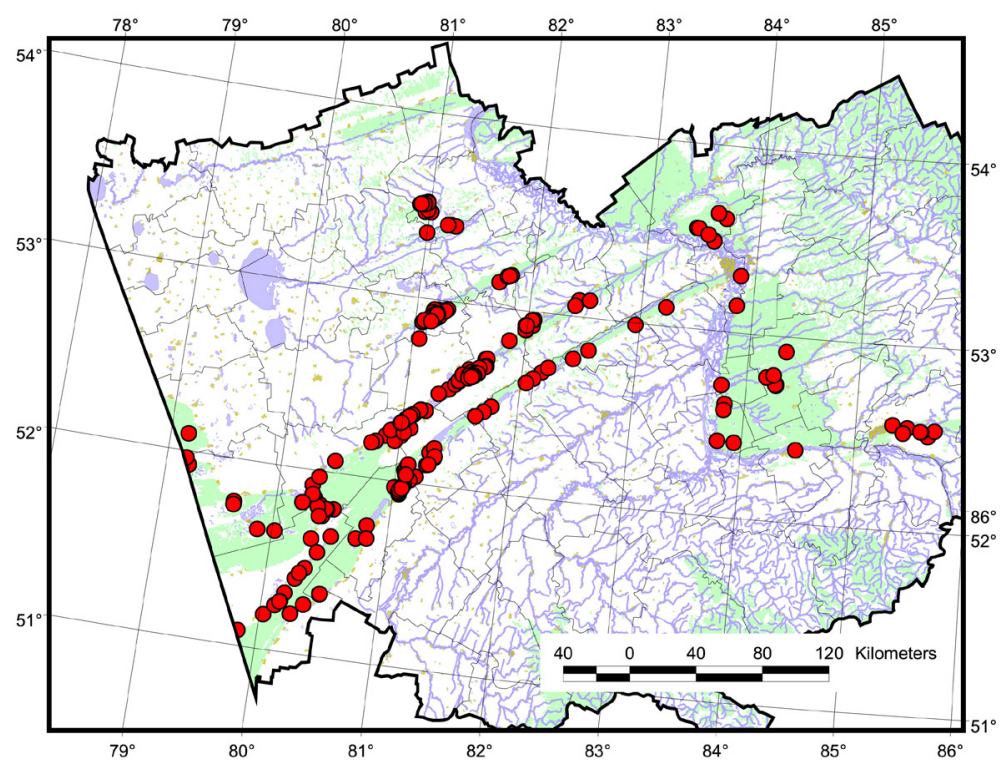

по опушкам боровых лент, но обшая численность гнездяшихся пар если и снизимась, то незначительно (рис. 6). Сейчас в борах остаётся активными 80-85 известных гнездовых участков, а численность по прежнему оценивается порядка 120-130 гнездяшихся пар.

Аругой вих, численность которого катастрофически сократилась в ленточных борах Алтайского края, нарялу с беркутом, - балобан. ОАнако причины, определившие исчезновение балобана, несколько иные. Определённо, что бамобан страдаи из-за рубок, так как гнездовые постройки орлов, в которых он размножался, в небольшом количестве уничтожаиись ежегодно. Но определил исчезновение балобана нелегальный отлов птиц. Этот сокол является популярной охотничьей птицей у сокольников на Ближнем Востоке, птицы из популяции алтайских боров были ком-

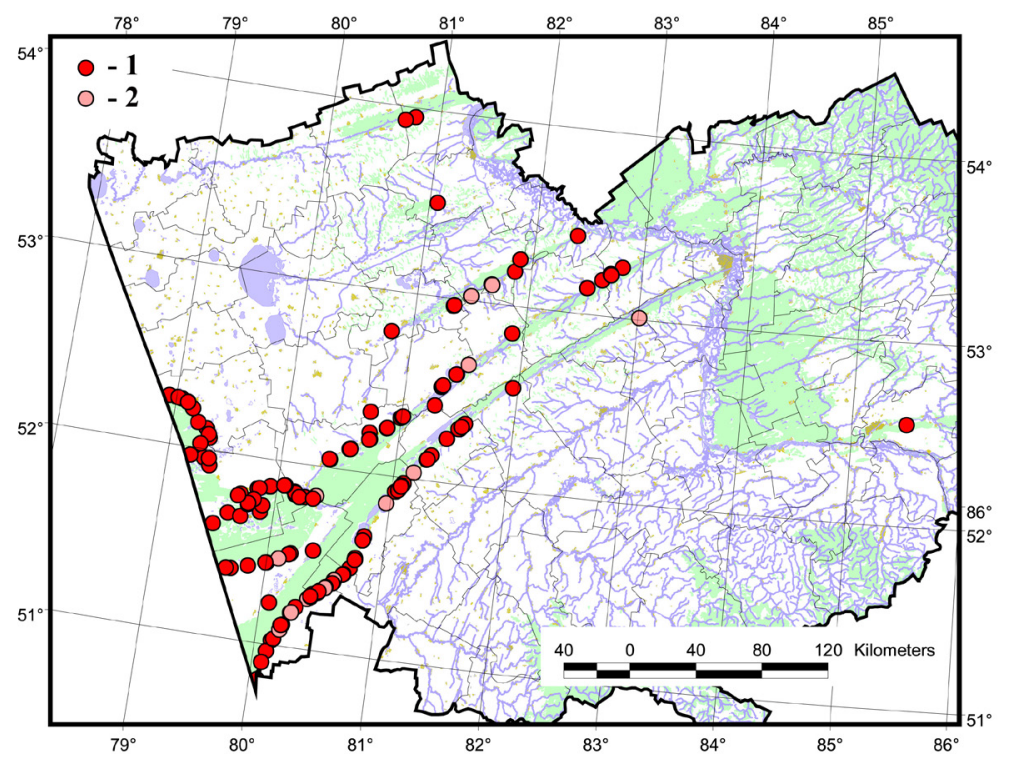

Рис. 5. Современное распространение большого подорлика (Aquila clanga) в алтайских борах: занятые гнездовые участки по состоянию на 2015 г.

Fig. 5. Modern distribution of the Greater Spotted Eagle (Aquila clanga) in the Altai pine-forests: occupied breeding territories to 2015.

Creating of SPFZ is a form of protection of forest communities specified by Russian legislation, art. 102 of the Forest Code of the Russian Federation (FC RF). According to this article, habitats of rare and endangered wildlife are included in the SPFZs. Legal regime of SPFZs (art. 107 FC RF) defines that SPFZ can be situated in conservation, exploitation and reserve forests. In exploitation forests on SPFZs it's forbidden to cut the forest clear; agriculture except haying and beekeeping; placing of objects of capital construction except linear objects and waterworks. Thus, the creating of SPFZ is legally one of the least expensive (in time and financial resources) ways of territorial protection of perennial breeding territories of many raptor species, listed both in the Red Data Book of Russia and regional Red Data Books.

In modern Russia it's impossible to save valuable forest territories outside federal PAs from full destruction, unless the state authorities use them to gain income through their business-structures. However, it's possible to save rare species nesting on valuable forest territories, while those territories are exploited by state authorities. While forest is profitable, it doesn't burn. Full prohibition of felling will lead to ceasing of realization of fire preventive measures, or maybe to aimed arsons with subsequent sanitary felling. If one cannot cut in the reserve, one can burn it and then there would be no prohibitions on felling. Thus, in this political situation, when state conservation authorities are paralyzed by the corruption and aren't able to perform their function, the only way

Рис. 6. Распространение орла-могильника (Aquila heliaca) в алтайских борах: 1 - гнездовые участки, занимавшиеся в 2008-2015 гг., 2 - гнездовые участки, занимавшиеся $А$ 2008 г.

Fig. 6. Distribution of the Imperial Eagle (Aquila heliaca) in the Altai pine-forests: 1 - breeding territories occupied in 2008-2015, 2 - breeding territories occupied before 2008. 


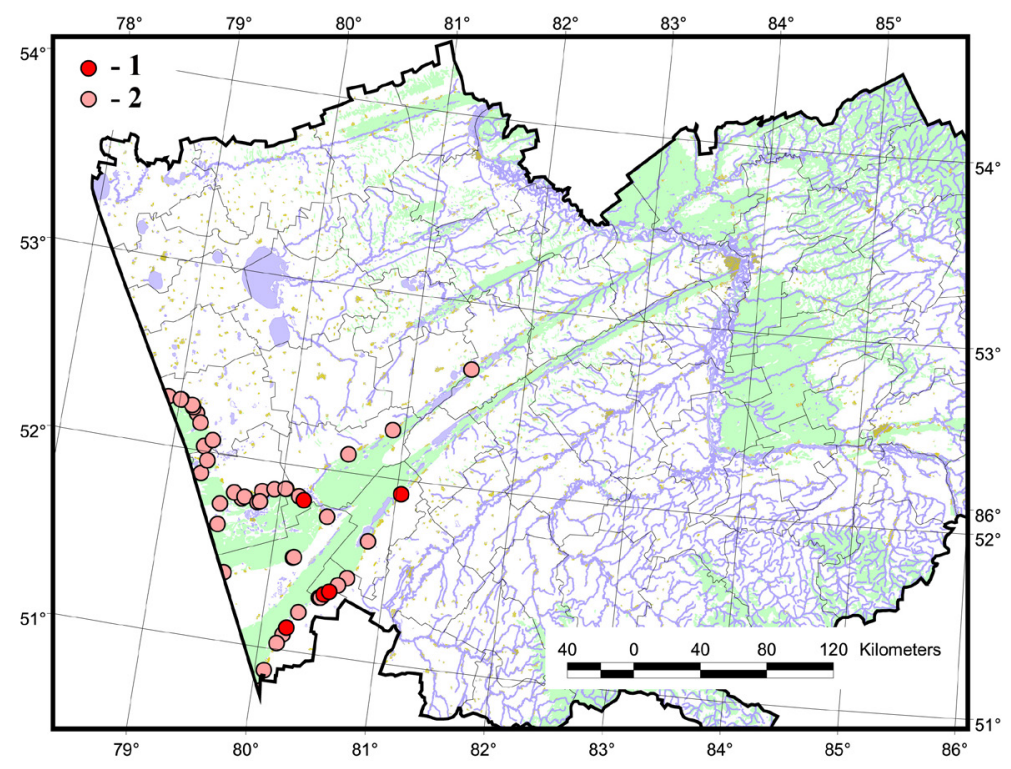

мерчески интересны, поэтому пресс их отлова был беспрецелентным последние 10 лет. В ленточных борах до 2006 г. сохранялась гнездовая группировка, численностью более 60-80 пар, в которой только в 2003 г. было локализовано 32 гнездовых участка соколов (Карякин и мр., 2005). В 2008-10 гг. зАесь было проверено 8 участков, 3 из которых были успешными, в 2011-2013 гг. - 11, два из которых успешные. В 2014 г. из проверенного 21 гнездового участка занятым оказался кишь 1 (успешный на момент проверки) (рис. 7). Таким образом, был констатирован фракт сокрашения численности боровой популяции балобана на 95 \% (Карякин и Ар., 2014). Современная численность балобана в ленточных бора оценивается в 3-5 пар, сохранившихся, преимушественно, на российскоказахстанской границе.

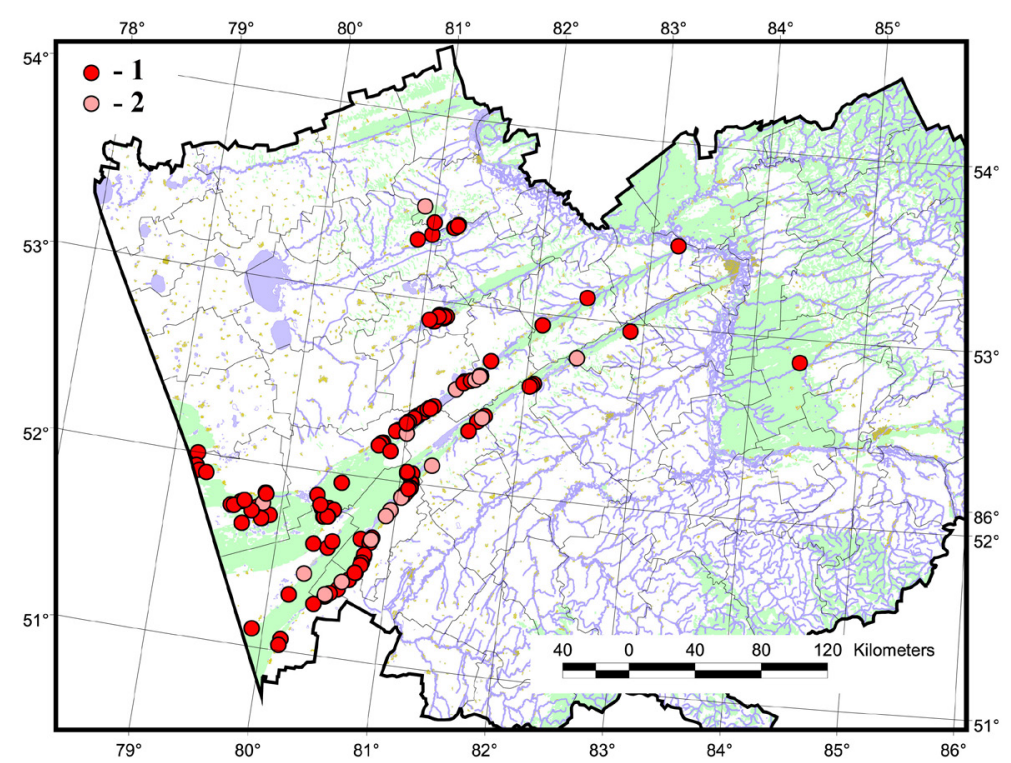

Рис. 7. Распространение балобана (Falco cherrug) в аитайских борах: 1 - гнездовые участки, занимавшиеся в 2008-2015 гг., 2 - гнездовые участки, занимавшиеся Ао 2008 г.

Fig. 7. Distribution of the Saker Falcon (Falco cherrug) in the Altai pine-forests: 1 - breeding territories occupied in 2008-2015, 2 - breeding territories occupied before 2008.

to save valuable forests and rare species of raptors nesting in them is protection of specific zones of the forests by the forces of loggers and on their free will. This is possible if one can compromise between exploiting and protecting.

Exactly for finding the compromise between exploiting the forests and rare species conservation, in 2013 an analysis of distribution of rare avian predators in strip-shaped pine forests of Altai Kray was conducted. There were also determined minimal parameters of SPFZs, which would allow rare raptor species' conservation nesting in strip-shaped pine forests with continued logging (Ravkin et al., 2013). Based on specific requirements of the birds of prey (table 2 ), the next method was used to create SPFZs in belt pine forests of Altai Kray:

1. SPFZ is defined around point-markers, which have geographical coordinates received by satellite navigator. The amount of markers on one area can be from 1 to 4 , mainly 1 , less often 2 or 3 . Such markers correspond to locations of nests situated either on a tree or (for some species) on the ground.

2. All apportionments crossed by $150 \mathrm{~m}$ radius from the point-markers should be included into SPFZ (fig. 9: A). The border of the SPFZ is drawn on the borders of those appointments. However, the appointments aren't "cut" by the 150 radius, but are defined by outside borders of the appointments which fall into $150 \mathrm{~m}$ area around the nest. Thus, in each case the area of SPFA is different and depends on the size of forest appointments which fall into $150 \mathrm{~m}$ radius

Рис. 8. Распространение филина (Bubo bubo) в аитайских борах: 1 - гнездовые участки, занимавшиеся в 2012-2015 гг., 2 - гнездовые участки, занимавшиеся $А о 2012$ г.

Fig. 8. Distribution of the Eagle Owl (Bubo bubo) in the Altai pine-forests: 1 - breeding territories occupied in 2012-2015, 2 - breeding territories occupied before 2012. 


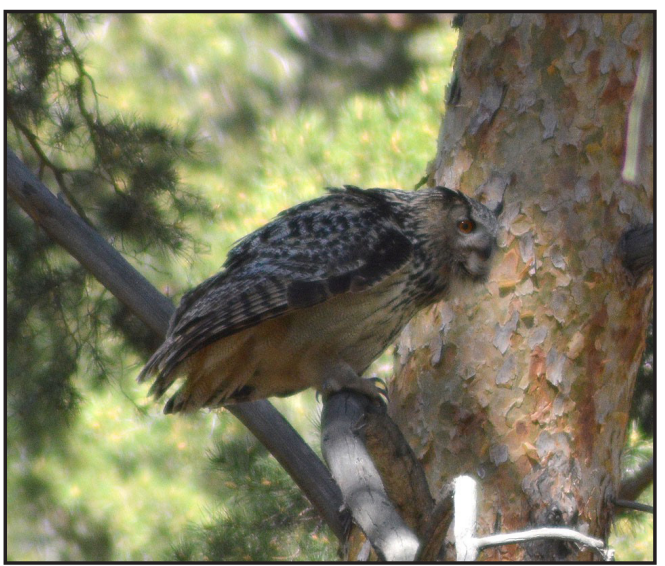

Фикин - характерный гнездяшийся ночной хишник менточных боров, в первую очередь страдаюший от рубок леса и оскуАения кормовой базы - зайцев и боровой Аичи, которые незаменимы мял фрилина в зимний период никакими Аругими видами. К концу 2014 г. в А^тайском крае было выявлено 167 гнездовых участков фрилинов, в том числе 110 гнездовых участков в ленточных борах в левобережье Оби $(65,9$ \% от обшего числа известных гнездовых участков в Алтайском крае) (рис. 8). За период с 2008 по 2014 гг. срилин прекратил размножение на 21 гнездовом участке, в том числе на 20 гнездовых участках в менточных борах. Занятыми к 2014 г. оставанись 146 гнездовых участков, в том числе 90 гнездовых участков в аитайских борах $(61,6 \%$ от обшего числа занятых гнездовых участков в Алтайском крае) (Карякин, 2014). Мониторинг, проведённый С.В. Важовым и А.В. Рыбальченко (2013) в 2012 г. показал, что филинами покинуто 14 (50 \%) гнездовых участков из 28 проверенных и ешё возможно на двух участках фрилины прекратили размножение (здесь были найдены только старые гнёзда). Сокрашение численности фрилина за 12 лет к 2014 г. составило 46 \%, при этом наиболее масштабные потери популяции произошли в период после 2007 г. в связи с активизацией рубок леса в менточных борах (Карякин, 2014).

Результаты мониторинга мест гнезцования хищных птиц в ленточных борах Амтайского края в 2015 году

В ходе обследования боровых заказников встречено более 250 особей (198 наблюдений на 196 точках) 16 видов пернатых хишников: 13 вилов соколообразных и 3 вида сов - филин, Алиннохвостая неясыть (Strix uralensis) и сплюшка (Otus scops) (табл. 1). Стоит отметить, что в 2015 г. практически выпали из наблюдения такие специализированные миосраги,
Филин (Bubo bubo). Фото И. Карякина.

Eagle Owl (Bubo bubo). Photo by I. Karyakin.

from markers (fig. 9: B).

3. The project of each SPFZ includes: a) a map with all SPFZ borders and forest appointments that belong to it; b) a table with the description of appointments and areas included in it.

For nature reserve territories, the SPFZ selection principle is important for the larger zoning of the territories on exploitation and special protection zones. In fact, zones of special protection should include forest areas with maximal concentration of SPFZs and unite them into larger clusters, the selection of which can partially follow the borders of the forest quarters.

Such method was realized in Zavyalovsky nature reserve (fig. 10) where zones of special protection were based on point-markers of rare species of raptors' breeding territories, complete with rare species of plants. The same approach was used in projecting protected areas in Kasmalinsky, Mamontovsky and Kornilovsky reserves in 2015.

Based on those methods of creating special protection zones, for three pine reserves - Kasmalinsky (155.75 km²), Mamontovsky $\left(92.78 \mathrm{~km}^{2}\right)$ and Kornilovsky $\left(176.0 \mathrm{~km}^{2}\right)$ and conducted researches, schemes of distribution of rare raptors' species breeding territories were designed. According to those scheme, for every nesting site SPFZ were marked on afforestation plans, depending on minimal parameters of SPFA selection, specific for different species (table 2). Then SPFZs were united into larger projected nature reserve special protection zones (NRSPZ), considering the presence of biotopes suitable for rare species' nesting, concentration of common species of raptors, and presence of chiropteran colonies and habitats of rare plants' growth. As a result, NRSPZs were projected for every reserve. In Kasmalinsky reserve the projected NRSPZ area sustains $86.56 \mathrm{~km}^{2}$, which is $55.57 \%$ of reserve area (fig. 11: A). In Mamontovsky reserve the projected NRSPZ area sustained $23.15 \mathrm{~km}^{2}$, which is $24.95 \%$ of reserve area (fig. 11: B). In Kornilovsky reserve the projected NRSPZ area sustained $51.04 \mathrm{~km}^{2}$, which is $29.0 \%$ of reserve area (fig. 11: C).

During the monitoring of rare species of birds of prey in pine forest nature reserves of the Altai Kray in 2015 numerous violation 
Табл. 1. Обследованные гнездовые участки пернатых хищников в боровых заказниках Аитайского края в 2015 г. (жирным выделены виды, внесённые в Красную книгу РФ).

Table 1. Surveyed breeding territories of raptors in the Nature Reserves of the Altai pine-forests in 2015 (bold font indicates of species included in the Red Data Book of Russian Federation).

\begin{tabular}{|c|c|c|c|c|c|}
\hline Вим / Species & $\begin{array}{l}\text { Tочки } \\
\text { Points } \\
\end{array}$ & $\begin{array}{r}\text { Наблюдения } \\
\text { Records } \\
\end{array}$ & $\begin{array}{l}\text { Гнездовые участки } \\
\text { Breeding territories }\end{array}$ & $\begin{array}{c}\text { Занятые гнёзАа } \\
\text { Occupied nests }\end{array}$ & $\begin{array}{r}\text { Жимые гнёзАа } \\
\text { Living nests }\end{array}$ \\
\hline Орлан-белохвост (Haliaeetus albicilla) & 14 & 15 & 7 & 3 & 3 \\
\hline Беркут (Aquila chrysaetos) & 1 & 1 & 1 & & \\
\hline Орёл-могильник (Aquila heliaca) & 3 & 3 & 2 & 2 & 1 \\
\hline Большой подорлик (Aquila clanga) & 30 & 31 & 24 & 12 & 10 \\
\hline Канюк (Buteo buteo) & 12 & 12 & 11 & 4 & 2 \\
\hline Ocoes (Pernis apivorus) & 7 & 7 & 7 & 3 & 3 \\
\hline Чёрный коршун (Milvus migrans) & 87 & 87 & 82 & 36 & 30 \\
\hline Тетеревятник (Accipiter gentilis) & 7 & 7 & 4 & 4 & 3 \\
\hline Перепелятник (Accipiter nisus) & 11 & 11 & 7 & 6 & 5 \\
\hline Болотный мунь (Circus aeruginosus) & 1 & 1 & & & \\
\hline Бамобан (Falco cherrug) & 1 & 1 & & & \\
\hline Чеглок (Falco subbuteo) & 5 & 5 & 5 & 2 & 2 \\
\hline Пустельга (Falco tinnunculus) & 1 & 1 & 1 & 1 & 1 \\
\hline Филин (Bubo bubo) & 10 & 10 & 9 & 3 & 2 \\
\hline Аинннохвостая неясыть (Strix uralensis) & 4 & 4 & 4 & 3 & 3 \\
\hline Сплюшка (Otus scops) & 2 & 2 & 2 & 2 & 2 \\
\hline
\end{tabular}

как светлые луни (Circus sp.), ушастая и болотная совы (Asio otus, A. flammeus), и была низкой численность канюка, что связано напрямую с депрессией численности мелких мышевидных грызунов в равнинной части Обского левобережья.

Самый массовый гнездяшийся вид менточных боров - это чёрный коршун (Milvus migrans) и именно его чаше все-
Слёток коршуна (Milvus migrans) в гнезде. Фото И. Карякина.

Fledgling of the Black Kite (Milvus migrans) in the nest.
Photo by I. Karyakin. го приходилось наблюдать в 2015 г.: бомее 100 регистраций птиц на 87 точках $(44,39 \%$ от обшего числа точек регистрации хищников), в том числе 82 гнезАовых участка $(49,40 \%$ от обшего числа выявленных гнездовых участков пернатых

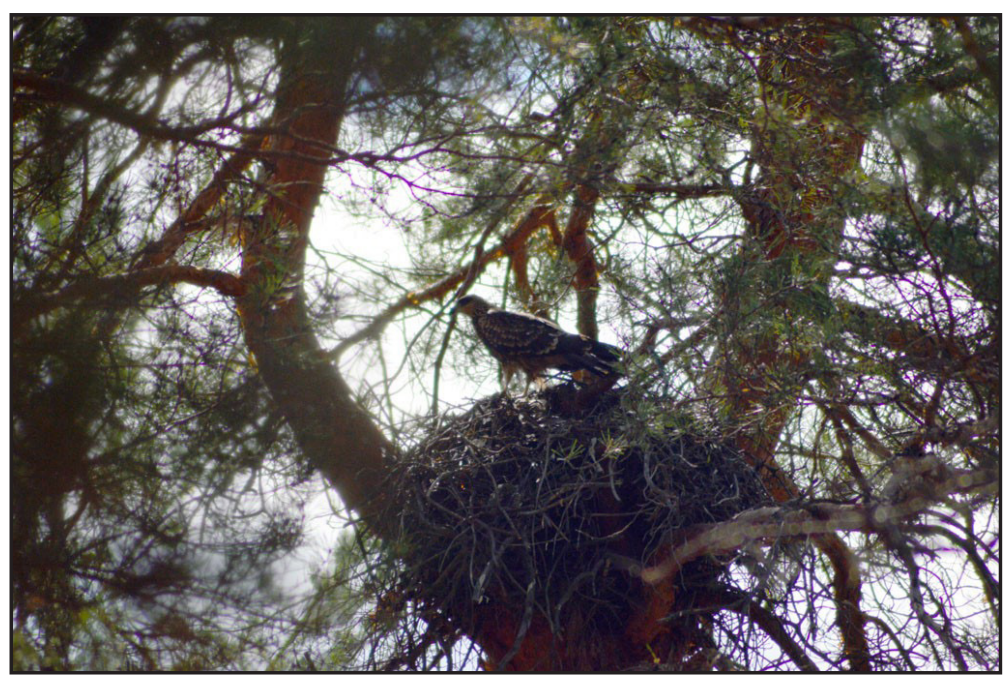

of legislation were found in felling on the

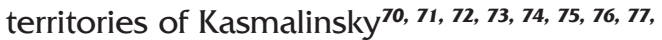
78, 79, 80, 81, 82, 83, 84, 85, 86, Mamontovsky ${ }^{91,92}$, Zavyalovsky 101, 102, 103, 104, 106 and Kornilovsky ${ }^{108,}$ 109, 110 reserves and in their neighborhood ${ }^{33,}$ 94, 95, 96, confirmed the destruction of nests of such rare species as the Eagle Owl and the Greater Spotted Eagle on the reserve territory, found breeding territories of bird species listed in the Red Book designated for felling in 2015-2016, sites that were included in state register of rare species of Altai Kray, including special protection zones in Zavyalovsky reserve.

From the review of environmental legislation violations in forest exploiting in pine forest nature reserves of the Altai Kray, it can be concluded that forest users will try to fell forest despite violating environmental legislation. With full incapacity of state authorities in nature conservation in Altai Kray, loggers will attempt to fell even in PAs. Only regular voluntary inspections will save valuable forest territories from destruction. Creating SPFZs on forest territories outside PAs and NRSPZs isn't a cure-all, but just a step towards making it hard for the loggers to exploit the forests illegally, and towards more protected territories. Thus, all created SPFZs and NRSPZs must be controlled by the public on regular basis. 
хишников) и 30 жилых гнёзА. Аоля жилых гнёзд коршуна составила $83,33 \%$ от числа занятых гнездовых участков и $36,59 \%$ от числа посешавшихся. Столь низкая занятость гнёзд наблюдалась впервые за 13 мет мониторинга гнездовой группировки чёрного коршуна в борах А^тайского края и объясняется плохими кормовыми условиями и Аобычей взрослых коршунов на гнездовых участках более крупными хишниками, такими как фрилин, орлан-белохвост и орёл-могильник. Аоля гнездовых участков, брошенных птицами в результате рубок, составила 14,63 \%, что соответствует среднегодовым показателям за 8 лет (ежегодный отход гнёзА по причине рубок варьирует в диапазоне от 12 мо $18 \%$ ). В этом году на соне депрессии численности мелких мышевидных грызунов, Аостаточно много выводков коршунов было уничтожено фрилинами, подорликами и орланами.

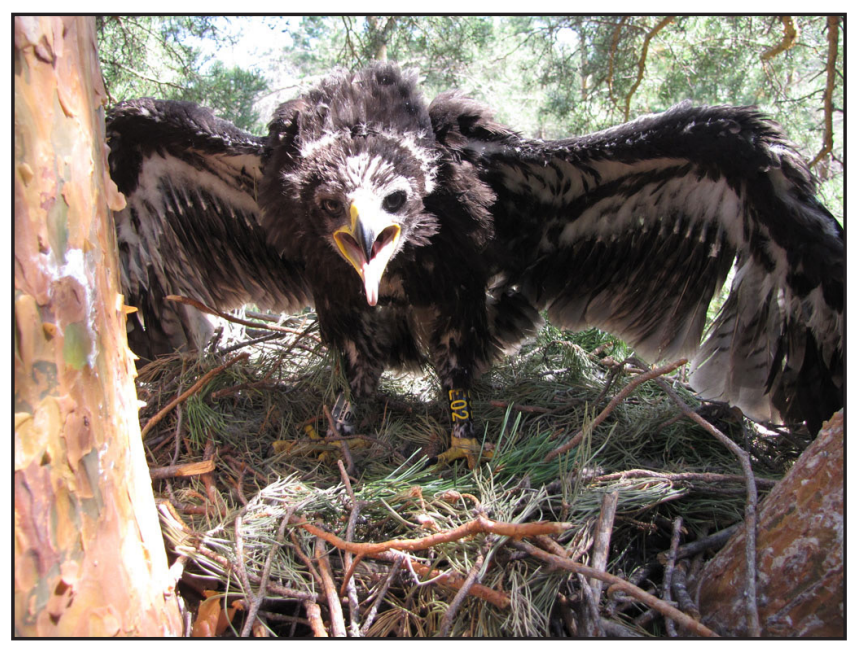

Птенец большого поцорлика в гнезде. Фото И. Карякина.

Nestling of the Greater Spotted Eagle in the nest.

Photo by I. Karyakin.
По сути все 16,67 \% пустуюших активных гнёзд на момент проверки мишились потомства в результате хишничества - останки птенцов или слётков были обнаружены съеденными на гнёздах, под ними или в непосредственной близости от них.

В результате полевых исследований также было осмотрено 24 гнездовых участка больших подорликов, 9 гнездовых участков срилинов, 7 гнездовых участков орланов-белохвостов, 2 гнездовых участка орАов-могильников и один гнезАОвой участок беркутов (табл. 1).

Последний известный гнездовой участок беркута в борах А^тайского края, видимо, прекратил своё сушествование - его многолетнее гнездо в Корниловском заказнике было занято большим подорликом. Подробнее о ситуации с беркутом в ленточных борах, см. в обзоре выше.

В 2015 г. было выявлено Ава новых гнездовых участка орлов-могильников в Касмаяинском и Корнияовском заказниках, на одном из которых в Касмаминском гнезАо было жилым - в нём на момент обследования находился практически полностью оперенный птенец (один из птенцов в выводке погиб в месячном возрасте и был выкинут из гнезда птицами). Известные ранее гнездовые участки могильников в 2015 г. не посещались.

Из 24 гнездовых участков больших поАорликов, которые удалось посетить в ходе экспедиции, на половине обнаружены гнёзда: 12 занятых (50 \%), из которых 10 жилых (83,33 \% от числа занятых и 41,67 \% от числа посешавшихся) с одним птенцом в каждом. На 5 гнёздах птенцов удалось окольцевать. Примерно на половине участков занятые гнёзда не были найдены, так как часть участков постралала в результате рубок и многолетние гнёзда подорликов были мибо брошены птицами, мибо попросту срублены лесорубами; часть участков (преимушественно в Корниловском и Касмалинском заказниках) была выявлена впервые и занятые гнёзда не удалось найти из-за лимита времени, хотя на 3-х участках наблюдались взрослые птицы, носившие к гнёздам Аобычу. Аоля гнёзА, брошенных по причине рубок, составила 20,83 \%, что несколько превышает среднегодовой показатель за последние 8 лет (ежегодный отход гнёзА подорлика по причине рубок варьирует в диапазоне от 10 мо $23 \%$ ). В этом году у подорликов в борах наблюАался самый низкий успех размножения за последние 10 лет - ни в одном гнезде не обнаружено выводка из 2-х птенцов. Связано это в первую очередь с депрессией численности мелких мышевидных грызунов (серые Microtus sp. и рыжие полёвки Clethrionomys sp.), которые практически полностью выпали из рациона подорликов. Тем не менее, численность водяной полёвки (Arvicola terrestris) осталась стабильной, что позволило избежать полной гибели птенцов в выводках. Это был первый год, когАа во всех гнёздах поАорлика наблюдалась рыба. Но если в Завьяловском заказнике это можно связать с сильнейшим затоплением его территории, впервые за последние 15 лет, и всплеском численности карася (Carassius sp.) во всех водоёмах заказника, то в сухом Касмаиинском заказнике постоянное присутствие рыбы в питании пары, гнездяшейся в центре боровой менты, просто необъяснимо. Крупные объекты питания, такие как цапли 
Большой подорлик. Фото И. Карякина.

Greater Spotted Eagle. Photo by I. Karyakin.

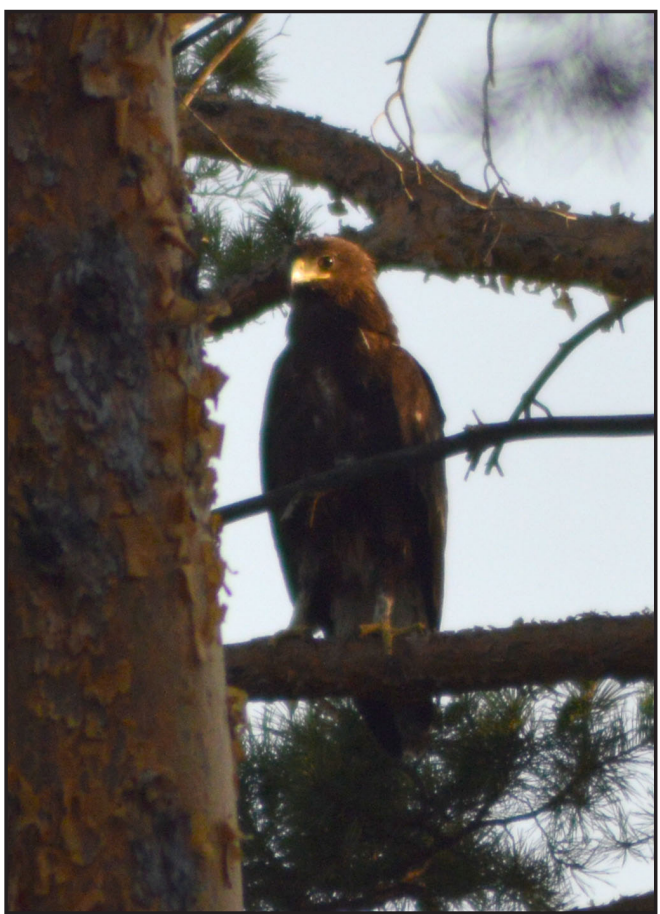

(Ardea cinerea, Casmerodius albus), в этом году вовсе отсутствоваии в питании проверенных пар подорликов. Тем не менее, в Корниловском заказнике удалось наблюдать успешную групповую охоту трёх больших подорликов (пары и самца с соседнего участка) на выводок серых журавмей (Grus grus) ${ }^{68}$.

На 7 гнездовых участках орлана-белохвоста найдено 3 занятых гнезда, во всех трёх размножение прошло успешно около гнёзд встречены слётки. В Мамонтовском заказнике впервые мля ленточных боров в 2015 г. был выявлен гнездовой участок орланов с Авумя гнездовыми постройками (жилой и старой на усохшей сосне), располагаюшимися на внешней опушке боровой менты в удамении от озёр и болот. В данном случае орланы заняли участок, ранее занимавшийся ор^ом-могильником, вытеснив последнего из этой части бора. Помимо этого в Мамонтовском заказнике найдены гнёзда 2-х пар на давно известных участках, пострадавших от рубок, и в Корниловском заказнике обнаружено новое гнездо орланов на новом многолетнем гнездовом участке. В Завьяловском заказнике численность орланов с 2004 г. к 2015 г. увемичилась с 1 гнездяшейся пары $о$ 3-х, а в 2014 г. начал формироваться 4-й участок, на котором обе птицы в паре в возрасте 4-х лет. В 2015 г. эта новая пара заняла участок подорликов, изгнав птиц из их многолетнего гнезАа на Аругую сторону озера, но пока своего гнезда птицы не построили.

Из 9 осмотренных гнездовых участков филинов, на 3-х были выявлены занятые гнёзда (33,33 \%), 2 из которых оказались успешными $(66,67$ \% от числа занятых гнёзА и 22,22 \% от числа посешавшихся участков) - их покинули птенцы (по оАному слётку около кажАого гнезда вокамизировами в ночное время). Чуть менее половины гнездовых участков (44,44\%) пустоваяи по причине рубок, которые были проведены в непосредственной близости от гнёзА.
Многолетнее гнездо орлана в Корниловском заказнике (сиева) и одно из гнёзд орлана, появившихся на боровой опушке в удалении от озёр, в Мамонтовском заказнике (справа).

Фото И. Карякина.

Perennial nest of the White-Tailed Eagle in the Kornilovsky Nature Reserve (at the left) and one of the nests of the White-Tailed Eagle appeared on the edge of the pine-forest remoted from the lake in the Mamontovsky Nature Reserve (at the right).

Photos by I. Karyakin.

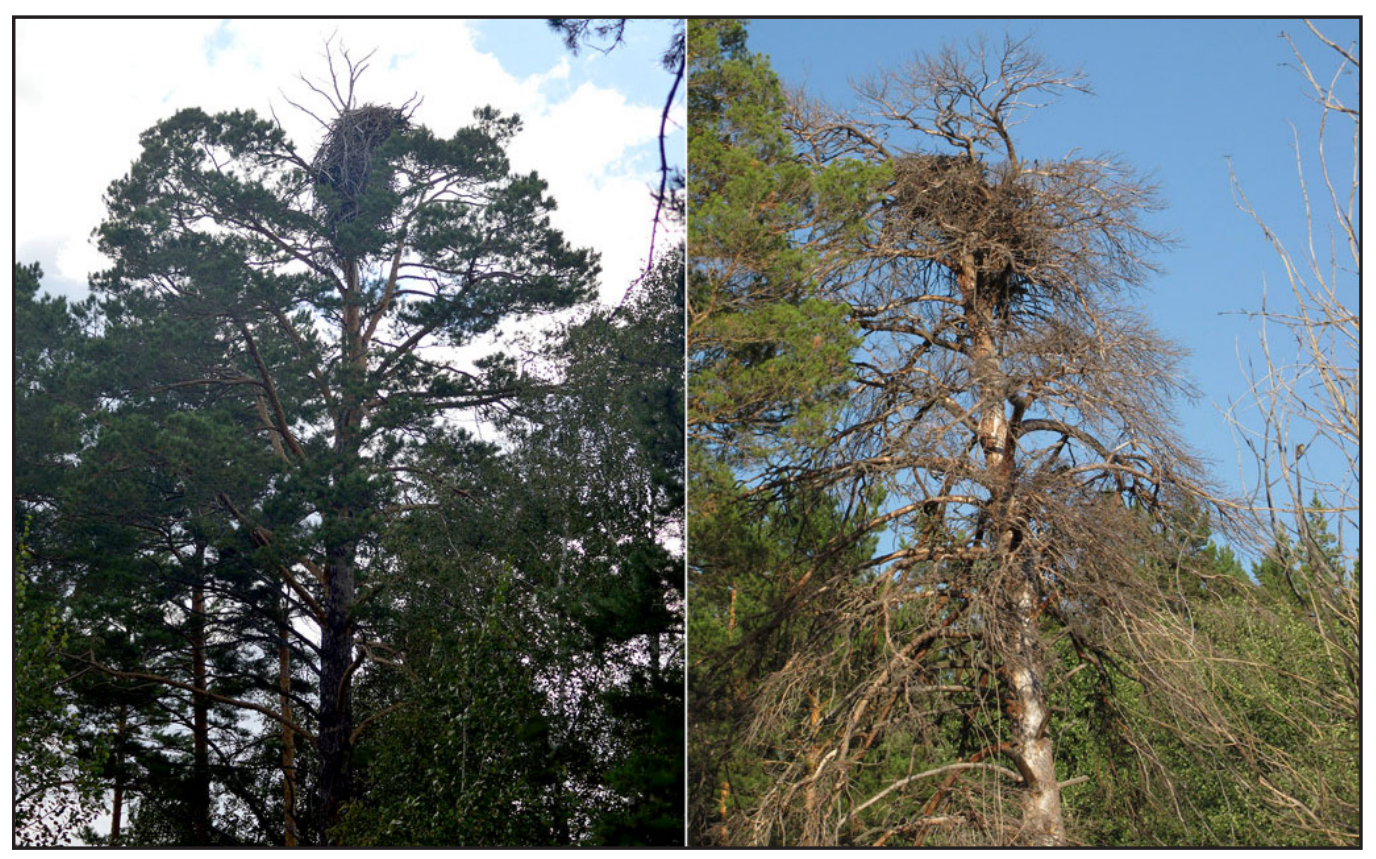


Гнездо большого подорлика в ЗавьяАовском заказнике в результате подтопления территории оказалось на острове. Фото И. Карякина.

As a result of inundation the nest of the Greater Spotted Eagle in the Zavyalovsky Nature Reserve turned out to be situated on the island.

Photo by I. Karyakin.

\section{Особо зашитные участки леса как ком- промисс между экспиуатацией лесов и охраной реАких вицов}

Как видно из обзора состояния редких виАов хишных птиц в ленточных борах А^тайского края и результатов мониторинга в 2015 г., уничтожение гнёзА в ходе рубок является важной составляюшей сокрашения численности реАких виАов. Очевидно, что мия искиючения рубок взять под территориальную охрану в качестве ООПТ фелерального статуса, даже основные гнездовые группировки хишных птиц в ленточных борах, невозможно. Этот процесс, во-первых, столкнётся с сильнейшим сопротивлением лесозаготовителей, асфилированных с властью, во-вторых, эти гнездовые группировки сосредоточенны на большей части боров, и даже ООПТ киастерного типа разумной плошали не вкАючит и половину известных гнездовых участков реАких вилов. В ленточных борах единственным выходом мия охраны мест гнездования хищных птиц может стать созАание особо зашитных участков леса ( $\Delta$ алее ОЗУА) на гнездовых участках редких виАОв хищных птиц.

ОЗУЛ - форма охраны лесных сообшеств, предусмотренная российским законодательством, а именно ст. 102 Аесного кодекса Российской Федерации (далее АК

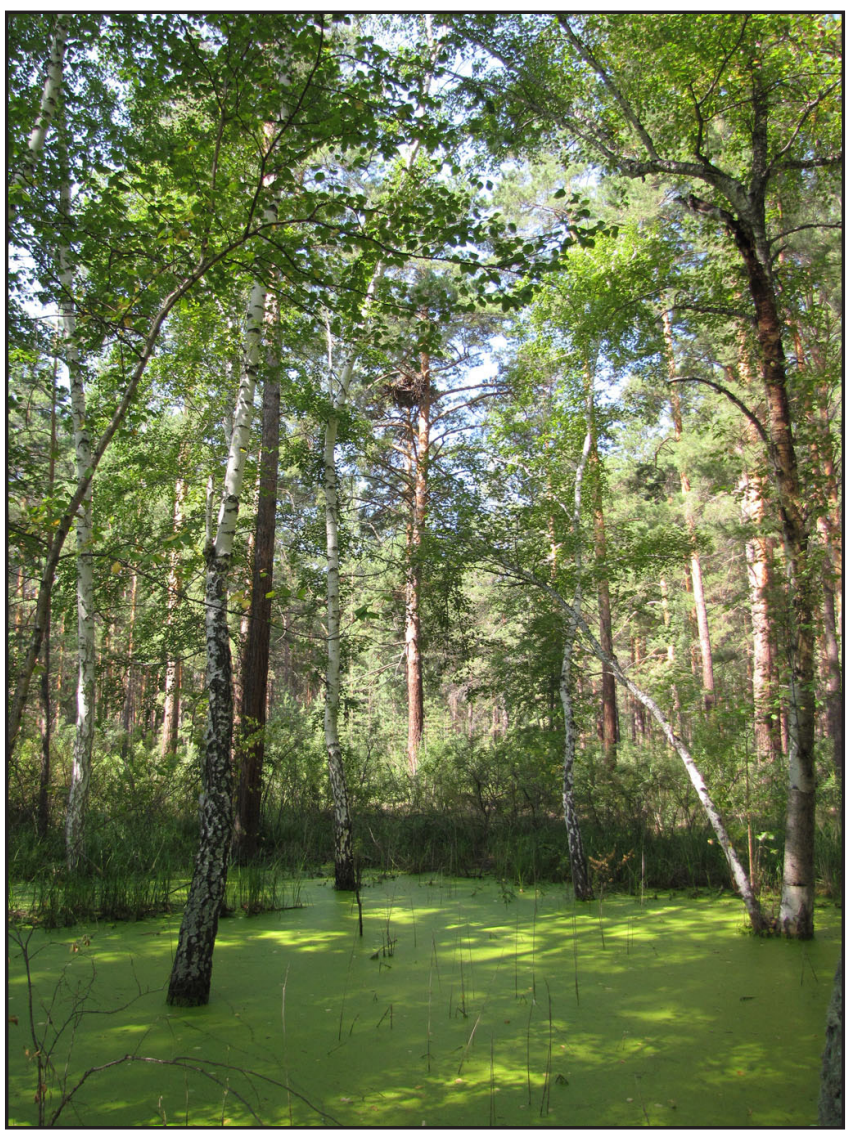

РФ). Согласно Аанной статье, к ОЗУА относятся и места обитания редких и нахоАяшихся под угрозой исчезновения Аиких животных. Правовой режим особо зашитных участков лесов (ст. 107 АК РФ) определяет, что ОЗУА может быть вылелена в зашитных, экспиуатационных и резервных лесах. В эксплуатационных лесах на особо зашитных участках месов запрешается проведение сплошных рубок лесных насаждений; ведение сельского хозяйства за искиючением сенокошения и пчеловодства; размещение объектов капитаиьного строительства, за искиючением минейных объектов и гидротехнических сооружений. Выхеление ОЗУА и установление их границ осушествляются органами государственной власти, органами местного самоуправления в пределах их полномочий, определённых в соответствии со статьями 81-84 ᄉК (в ред. Федерального закона от 29.12.2010 № 442-Ф3). Таким образом, создание ОЗУЛ в правовом отношении один из менее затратных (по временным и финансовым ресурсам) способов территориальной охраны многолетних гнезАОвых Участков целого ряда видов хишных птиц, занесённых как в Красную книгу РФ, так и в региональные Красные книги.

ОЗУЛ как форма охраны мест обитания и гнездования редких видов птиц Аавно апробирована в ряде стран Европы. В России системы ОЗУЛ утвержАены Рослесхозом дмя многих регионов, но Аалеко не везде ОЗУЛ выделены с учётом мест обитаний реАких виАов.

В соответствии с нормативами и признаками выделения ОЗУА, определённых приложением 4 к Лесоустроительной инструкции, утвержАённой приказом Росмесхоза № 516 от 12 мекабря 2011 г., к ним могут быть отнесены (п. 6) места обитания редких и находяшихся под угрозой исчезновения диких животных. Площаць и границы каждого такого участка устанавливаются на основании специамьных обследований и обоснований и не определены нормативами Лесоустроительной инструкции. Таким образом, какой-либо официальной методики или регламента выделения ОЗУА в местах обитания редких видов не сушествует.

Опыт создания ОЗУА на основе методики, обеспечиваюшей сохранение различных реликтовых лесных сообшеств и мест обитания редких видов растений и животных, включая места обитания таких редких видов пернатых хишников, как хохлатый орёл (Nisaetus nipalensis) и рыбный филин 


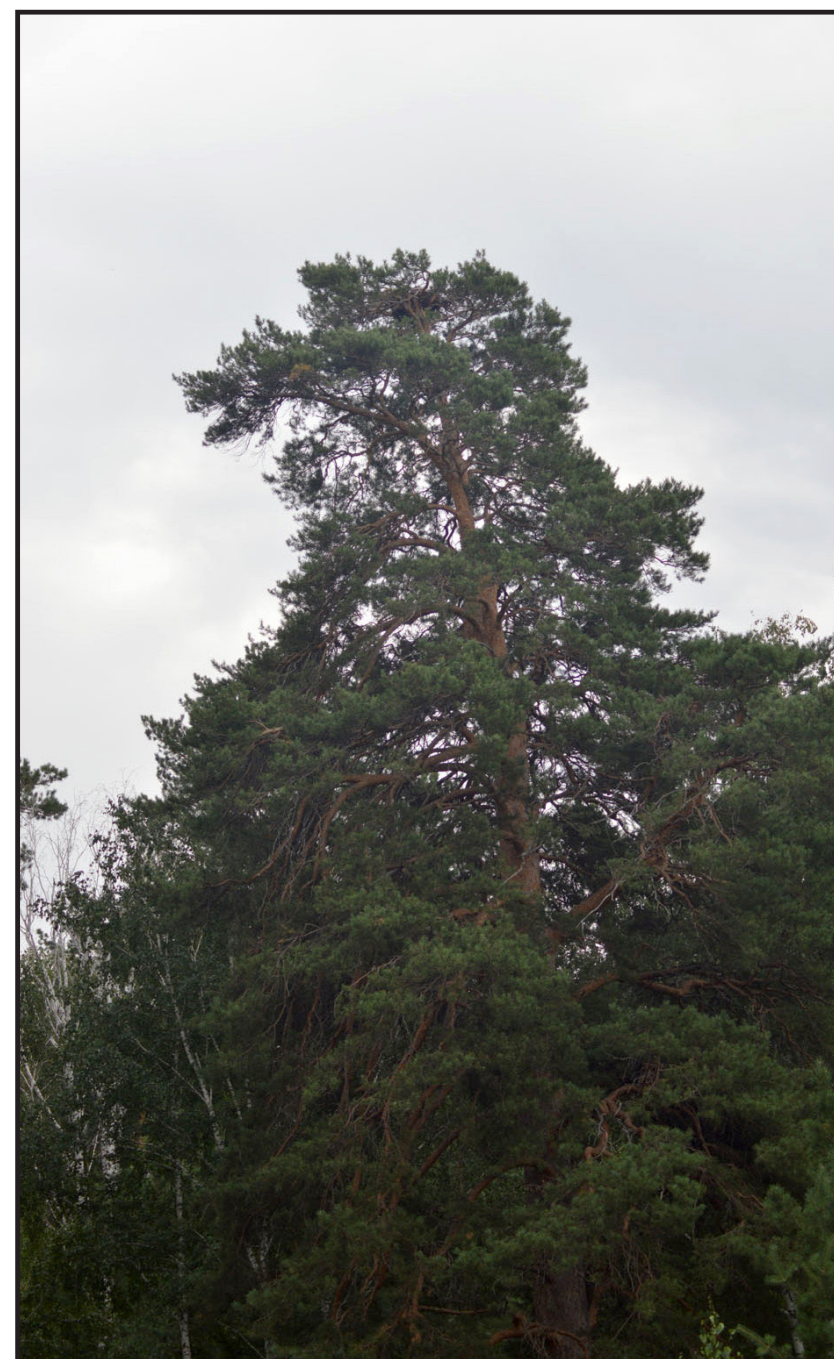

Гнёзда редких видов хищных птиц: вверху - жилое гнездо орла-могияьника (Aquila heliaca) в Касмаиинском заказнике на участке, отведённом в рубку, внизу - гнездо орлана-белохвоста на берегу озера в Мамонтовском заказнике на участке, пройценном рубками, брошено птицами и постепенно разрушается. Фото И. Карякина.

Nests of the rare birds of prey: upper - of the Imperial Eagle (Aquila heliaca) located in the part of forest designated for logging in the Kasmalinsky Nature Reserve, bottom - the abandoned and gradually destroying nest of the White-Tailed Eagle from the cut down part of the forest near the lake in the Mamontovsky Nature Reserve. Photo by I. Karyakin.

(Ketupa blakistoni), имеется на Ааиьнем Востоке (Арамильев и Ар., 2010). Этими рекомендациями регламентировалось выделение в качестве ОЗУЛ участка леса в рахиусе 500 м вокруг многолетнего гнезда птицы, занесённой в Красную книгу РФ. Методика прошла процедуру согласования на Учёном совете ФГУ "АаиьНИИКХ" в агентстве лесного хозяйства по Еврейской автономной области и Хабаровскому краю, а также в $\triangle$ аиьневосточном государственном лесоустроительном предприятии (Кобяков, Яницкая, 2007). На территории аренды лесозаготовительной компании "Тернейлес", гле сосредоточена крупнейшая в России гнездовая группировка рыбного фрилина, отработана методика вылеления ОЗУЛ, как в местах установленного, так и в местах потенциамьного гнездования рыбного филина. В последнем случае предложена бусрерная зона 100 м вокруг рек с подходяшими условиями Амя гнезАования рыбного фрилина (Slaght, Surmach, 2015).

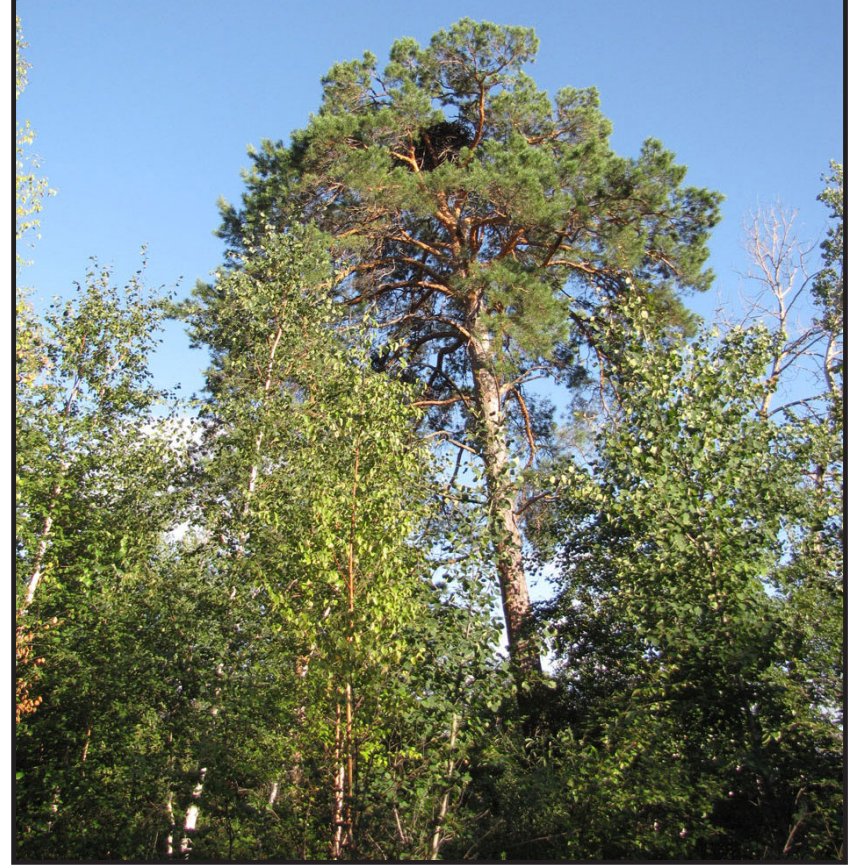

Какими Аолжны быть параметры ОЗУА вокруг гнёзА хишных птиц - это вопрос Аискуссионный. В частности С.Г. Витер (2014) на основании данных о минимаиьном расстоянии межАу гнездяшимися парами разных видов хишных птиц в Украине, средних размерах гнездового участка (левобережная лесостепь и степь, Украина) и средних размерах участка, который находится поА особой охраной птиц в гнездовый период и в пределах которого гнездяшиеся птицы проявляют особое беспокойство по отношению к человеку (окрикивание, пикирование, сопровождение и пр.) рекомендует следуюшие размеры ОЗУА: мия орлана-белохвоста следует вылелять охранную зону с радиусом не менее 700 метров, мля орла-могильника - не менее 500 м (оптимум - от 600 Ао 700 м), мия малого подорлика (Aquila 
pomarina) - 400 м, ммя курганника (Buteo rufinus), осоела (Pernis apivorus) и орлакарлика (Hieraaetus pennatus) - не менее 300 м, мяя обыкновенного канюка (Buteo buteo), тетеревятника (Accipiter gentilis) и перепелятника (Accipiter nisus) - не менее 200 м (мя канюка более оптимальна охранная окологнездовая зона с радиусом около 300 м).

ОАнако, если вышеприведённые параметры применить к выделению ОЗУА в ленточных борах Алтайского края, гАе каждый гектар бора занят каким-нибудь виАОм хишных птиц, то вся плошаАь боров будет вылелена в оАин большой ОЗУА. Ал алтайских боров это конечно было бы более правильно, но, к сожалению, российские реалии не позволяют на это наАеяться.

Нало чётко понимать, что в современной России сохранить от полного уничтожения особо ценные лесные территории вне федеральных ООПТ невозможно, если власть не получает с них материальной прибыли (через свои бизнес-структуры). Но возможно сохранить редкие виды, гнездяшиеся на особо ценных лесных территориях, пока эти территории эксплуатируются и приносят прибыль государственным служашим. Пока лес приносит прибыль, он не горит. Полный запрет рубок на лесных территориях приведёт, как минимум, к прекрашению реаизации противопожарных мероприятий, а как максимум - к целевым поджогам с целью проведения санитарных рубок. Если в заказнике нельзя рубить, то его можно поджечь, после чего уже не будет никаких ограничений мяя запрета рубок. Следовательно, в сложившейся политической ситуации, когАа государственные органы охраны природы параяизованы коррупционными схемами

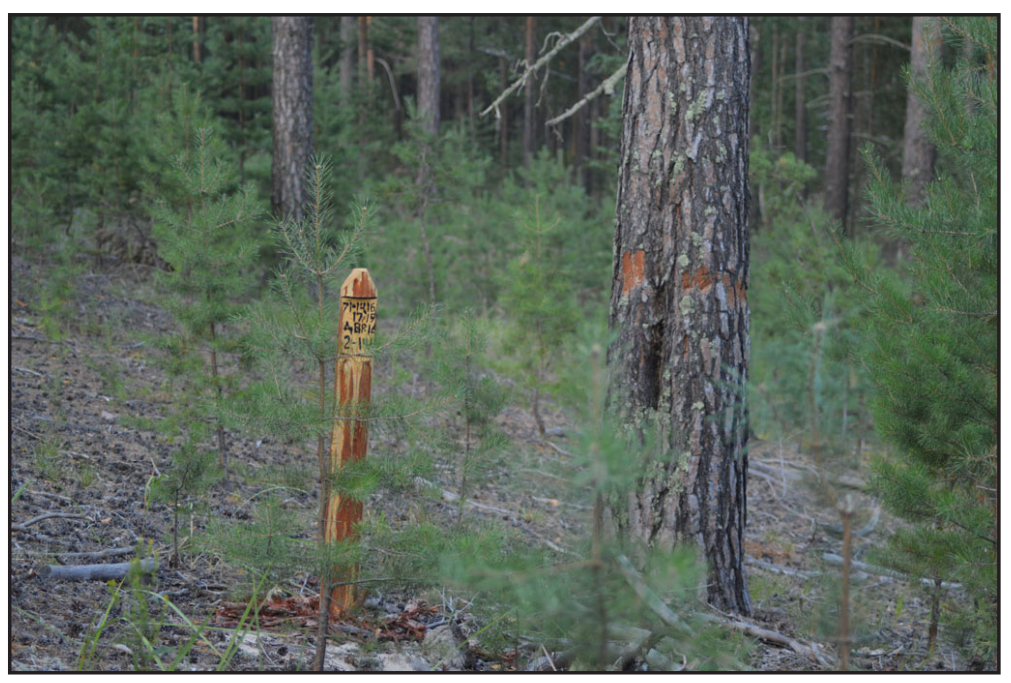

и не способны выполнять свои функции, единственный выход мия сохранения ценных лесов и реАКих виАОв хишных птиц, гнездяшихся в них, - это охрана определённых участков силами лесозаготовителей по их моброй воле. Такая схема возможно, если найден компромисс между эксплуатацией и охраной.

Именно с точки зрения нахождения компромисса межАу эксплуатацией лесов и охраной редких видов, в 2013 г. был осушествлён анализ распределения редких пернатых хишников в ленточных борах А^тайского края, и определены минимахьные параметры ОЗУА, с которыми возможно сохранение редких видов хишных птиц на гнездовании в ленточных борах при продолжаюшихся лесозаготовках.

Методика выделения особо зашитных участков леса и её амаптация к выцемению зон особой охраны в заказниках

Аля большинства хишников особо важную роль играет сохранность в ненарушенном виде территории гнездового участка. Особо чувствительны к изменениям на гнездовом участке такие виды, как филин, большой подорлик и беркут, менее чувствительны - бородатая неясыть (Strix nebulosa), орёл-могильник, орланбелохвост. Орёл-могильник и орлан-беАохвост могут гнездиться на одиночных старых деревьях или в группах старых деревьев. Аия сохранения этих видов на гнездовании достаточно сохранение территории в радиусе 80 м вокруг гнезда (табл. 2). Аия фрилина, большого подорлика и беркута крайне важно сохранение структуры леса на всём гнездовом участке, размер которого определяется птицами индивидуально в кажАом конкретном случае по определённым маркерам, которыми являются лесные опушки и одиночные старые деревья. У филина и большого подорлика имеется несколько гнёзд на участке, как правило, маркируюших охраняемый птицами центр участка. Аяя прекрашения гнездования этих видов

Аесосечный столбик, означающий отвод ^еса в рубку, и помеченные мя рубки деревья в проектируемой зоне особой охраны в Касмачинском заказнике. Фото И. Карякина.

The pole that marks woodcutting area and trees marked for logging in the projected special protection zone in the Kasmalinsky Nature Reserve.

Photo by I. Karyakin. 
Табл. 2. Параметры выцеления ОзУА мяя разных вицов пернатых хищников в ленточных борах Аитайского края, по: Равкин и мр., 2013.

Table 2. Parameters of the special protected forest zones for different raptor species in the Altai pine forests, from Ravkin et al., 2013.

\begin{tabular}{|c|c|c|c|c|c|}
\hline Вим / Species & $\begin{array}{l}\text { Расстояние } \\
\text { между соседями } \\
\text { (км) } \\
\text { Distance be- } \\
\text { tween neighbors } \\
\text { (km) }\end{array}$ & $\begin{array}{l}\text { Tипичные местообитания } \\
\text { Typical habitats }\end{array}$ & $\begin{array}{l}\text { Основные } \\
\text { объекты } \\
\text { питания } \\
\text { Main prey spe- } \\
\text { cies }\end{array}$ & $\begin{array}{l}\text { Основные угрозы } \\
\text { Main threats }\end{array}$ & $\begin{array}{l}\text { Охранная } \\
\text { зона (м) } \\
\text { Protected } \\
\text { zone }(\mathbf{m})\end{array}$ \\
\hline 1 & 2 & 3 & 4 & 5 & 6 \\
\hline $\begin{array}{l}\text { Беркут } \\
\text { Golden Eagle } \\
\text { Aquila chrysaetos }\end{array}$ & $>20$ & $\begin{array}{l}\text { Внутренние участки боров, богатых } \\
\text { озёрами и болотами. В большинстве } \\
\text { случаев избегает опушек и побере- } \\
\text { жий водоемов. Наиболее благо- } \\
\text { приятными участками мля гнездо- } \\
\text { вания являются гривы со старыми } \\
\text { соснами среди суходолов или среди } \\
\text { умеренно заболоченных открытых } \\
\text { участков, лишённых открытой воды. } \\
\text { Dry valley. Inner parts of the pine- } \\
\text { forests rich in lakes and marshes. In } \\
\text { most cases this species avoid forest } \\
\text { edges and riparian forests. The most }\end{array}$ & $\begin{array}{l}\text { Заяц / hares } \\
\text { (Lepus sp.), } \\
\text { тетеревиные / } \\
\text { grouses (Tetraoni- } \\
\text { dae), утки / ducks } \\
\text { (Anatidae) }\end{array}$ & $\begin{array}{l}\text { Вырубка гнездовых } \\
\text { деревьев, уничтожение } \\
\text { мест обитания, фактор } \\
\text { беспокойства (рубки) } \\
\text { на гнездовых участках с } \\
\text { марта по июль. Отстрел. } \\
\text { Cutting of the nesting } \\
\text { trees, habitat lost, habitat } \\
\text { disturbance (logging) on } \\
\text { the breeding territories } \\
\text { from March to July. } \\
\text { Shooting. }\end{array}$ & 150 \\
\hline
\end{tabular}

Орёл-могильник $3.5^{*}, 7.39^{* *}$ Imperial Eagle Aquila heliaca
$3.5^{*}, 7.39^{* *}$
$18.59^{* * *}(n=65$

(a) The most favorable areas for nesting are relief elevations covered with old pine trees amongst dry valleys or among the moderately swampy open areas without open water.

Гнездится по опушкам ленточных боров, особо предпочитает опушки, граничашие с нераспаханной степью (пастбишами). Аия гнездовых построек нуждается в старовозрастных соснах (старше 120 лет). This species nesting on the edges of strip-shaped pine forests, prefers forest edges above untilled steppe (pastures), requires old-growth pine trees (over 120 years) for nest placing.

Большой подорлик 5.94 (1.82-10.64) Необходима совокупность водноGreater Spotted $\quad(n=23)$ Eagle

Aquila clanga

болотных угодий и леса, состав и возраст леса особой роли не играют. ГнезАиться в угнетённых миственных лесах. В борах предпочитая селиться на участках с молодым лесом (60-80 лет) и менее разреженными. Основной критерий гнездового биотопа - намичие водоёма или крупного болота (порялка $1 \mathrm{kм}^{2}$ и более) в непосредственной близости от лесного массива или внутри него. ГнезАопригодной является также полоса леса вАоль водно-болотного комплекса. Need a totality of wetlands and forests (the forest composition and age are not decisive criteria). Breeds in the waterlogged deciduous forests. In the pine forests prefers to breed in areas with dense young forest $(60-80$ years). The main criteria of the breeding habitat is the presence of a large swamp or lake (about $1 \mathrm{~km}^{2}$ and more) in the vicinity of the forest or inside it. Favorable for nesting is the edge of the forest along the wetland.
Краснощекий Вырубка старовозрастсусиик / Redcheeked Ground Squirrel (Spermo- менточного бора, фактор philus erythrog- беспокойства (рубки) enys), врановые / на гнездовых участках с crows (Corvus sp.) апреля по август. В меньшей степени - гибель на ^ЭП и отстреА. Cutting of the nesting trees on the edges of pine forest, plowing of the steppes near the strip-shaped pine forests, habitat disturbance (logging) on the breeding territories from April to August. To a lesser extent - death from electrocution and shooting.

Водяная полевка Вырубка гнездовых / Water Vole (Arvicola ter- мест обитания, фактор restris), мелкие беспокойства (рубки) мышевидные на гнездовых участках с грызуны / small апреля по август. В меньmurine (Micro- шей степени - гибель на tinae, Muridae),

околоводные и Cutting of the nesting водоплавающие trees, habitat lost, habitat птицы / water- disturbance (logging) on birds and waders the breeding territories (Charadrii, Laridae, from April to August. To Rallidae, Podi- a lesser extent - death cepidae, Anatidae, from electrocution and Ardeidae), shooting. красношёкий сусиик / Redcheeked Ground Squirrel (Spermophilus erythrogenys) 


\begin{tabular}{lll}
\hline $\mathbf{1}$ & $\mathbf{2}$ & $\mathbf{3}$ \\
\hline Орлан-белохвост & $9.44(5.2-15.8)$ & Гнездится на участках старого со- \\
White-Tailed Eagle & $(n=4)$ & снового леса по берегам крупных \\
Haliaeetus albicilla & & озёр, окружённого заболоченными \\
& мелколесьями. \\
& This species nesting in areas of old \\
& pine forest on the banks of large \\
& lakes surrounded by marshy under- \\
& growth.
\end{tabular}

$\begin{array}{ll}\text { Сокол-балобан } & 5.23^{*}, 11.04^{* *}, \\ \text { Saker Falcon } & 41.39^{* * *}(n=28) \\ \text { Falco cherrug } & \end{array}$

Филин

Eagle Owl

Bubo bubo

Бородатая неясыть

Great Grey Owl Strix nebilosa
3.90 (0.99-8.70) Предпочитает совокупность водно$(n=23)$

еАиничные неравномерно распределённые пары single pairs are unevenly distributed

болотных угодий и леса, причем в месу тяготеет к старым участкам, в отличие от подорлика. В борах избегает молодых и закустаренных выделов, предпочитая гнездиться в старых разреженных лесах. Основным критерием, предъявляемым к гнезАовому биотопу, является намичие водоема или крупного болота (не менее $1 \mathrm{~km}^{2}$ ) в непосредственной близости от лесного массива или внутри него. ГнезАопригодной является полоса леса вАоль воАно-болотного комплекса. Также гнездится в старых борах вдоль нераспаханных участков степи. Need a totality of wetlands and forests, preferring old forests in contrast with the Greater Spotted Eagle. In pine forests it avoids parts of young forest and forest with lots of bushes, preferring parts of old sparse forest. The main criteria for nesting habitat is the presence of a large swamp or lake (not less than $1 \mathrm{~km}^{2}$ ) in the vicinity of the forest or inside it. Favorable for nesting is the edge of the forest alon the wetland. Also, it nesting in old pine forests along the native steppe.

^еса мюбого типа, граничашие с болотами и лугами. В Алтайском каре номанный виА, гнездящийся в годы пика численности ^есных полёвок. All types forests bordering with wetlands and meadows. In the Altai
Тяготеет к опушкам, т.к. подобно Краснощёкий могильнику охотится на пастбишах. сусиик / RedЗанимает гнёзда могильника (Aquila cheeked Ground heliaca), коршуна (Milvus migrans), Squirrel (Spermoберкута (Aquila chrysaetos), ворона (Corvus corax). This species nesting on the edge of a пишуха / Stepp pine forest, since it prefers hunting in Pika (Ochotona pastures. It occupied the old nests of pusilla), мелкие the Imperial Eagle (Aquila heliaca), Black Kite (Milvus migrans), Golden Eagle (Aquila chrysaetos) and Raven (Corvus corax). Kray this species is nomadic that stay for breeding during the years with a peak number of forest voles (Clethrionomys). murine (Microti-

4
Утки / ducks
(Anatidae), чайки
/ gulls (Laridae),
врановые / crows
(Corvus sp.), рыба
/ fish (Pisces)

\section{5} врановые / crows (Corvus sp.), голуби / pigeons (Columbidae), куропатковые / partridges (Perdicinae).

Водяная полёвка

/ Water Vole

(Arvicola terrestris), хомяк обыкновенный / European Hamster (Cricetus cricetus), серая крыса / Common Rat (Rattus norvegicus), зайцы / hares (Lepus sp.), степная пишуха / Steppe Pika (Ochotona pusilla), мелкие мышевидные грызуны / small murina, a также утки / duck (Anatidae), пастушковые / rails and crakes (Rallidae),

тетеревиные / grouses (Tetraonidae) и врановые / crows (Corvus sp.) птицы.

\section{Мелкие} мышевидные грызуны / small nae, Muridae)
Вырубка гнездовых Аеревьев, уничтожение мест обитания, фрактор беспокойства (рубки)

на гнездовых участках с марта по июль. Отстрел. Cutting of the nesting trees, habitat lost, habitat disturbance (logging) on the breeding territories from March to July. Shooting.

Отлов Аля нужА соколиной охоты. Фактор беспокойства с апреля по июль. Уничтожение мест обитаний - рубки, распашка степи вАоль боров. Гибель на АЭП.

Trapping for falconry. Habitat disturbance on the breeding territories from April to July. Habitat lost - logging, plowing of the steppes near the pine forests. Death from electrocution.

Вырубка гнездовых Аеревьев, уничтожение мест обитания, фрактор беспокойства (рубки) на гнездовых участках с марта по июль. Гибель на АЭП и отстрел. Cutting of the nesting trees, habitat lost, habitat disturbance (logging) on the breeding territories from March to July. Death from electrocution and shooting.

6

80

Вырубка леса на гнезцовых участках. В меньшей степени - гибель на АЭП и отстрел.

Habitat disturbance

(logging) on the breeding territories. To a lesser extent - the mortality of electrocution and shooting. 
в ряле случаев достаточно уничтожение присанных деревьев-маркеров гнездового участка. В свете этого, Аля сохранения этих видов необходимо отсутствие Аюбой хозяйственной Аеятельности в выделе, в котором находится активное гнездо и альтернативные гнёзда и в окружаюших этот вылел Аругих лесных вылелах в радиусе Ао 150 м от границы вылела, в котором находятся гнёзаа (Равкин и др., 2013). Основываясь на этих требованиях хищников, Аля вылеления ОЗУА в ленточных борах Алтайского края была применена следуюшая методика:

1. ОЗУА вылеляется вокруг точек-маркеров, кажхая из которых имеет геограсические координаты, полученные спутниковым навигатором. Количество маркеров на участке может быть от 1 Ао 4-х. В основном 1, реже 2 или 3. Аанные маркеры соответствуют месторасположениям гнёзд,

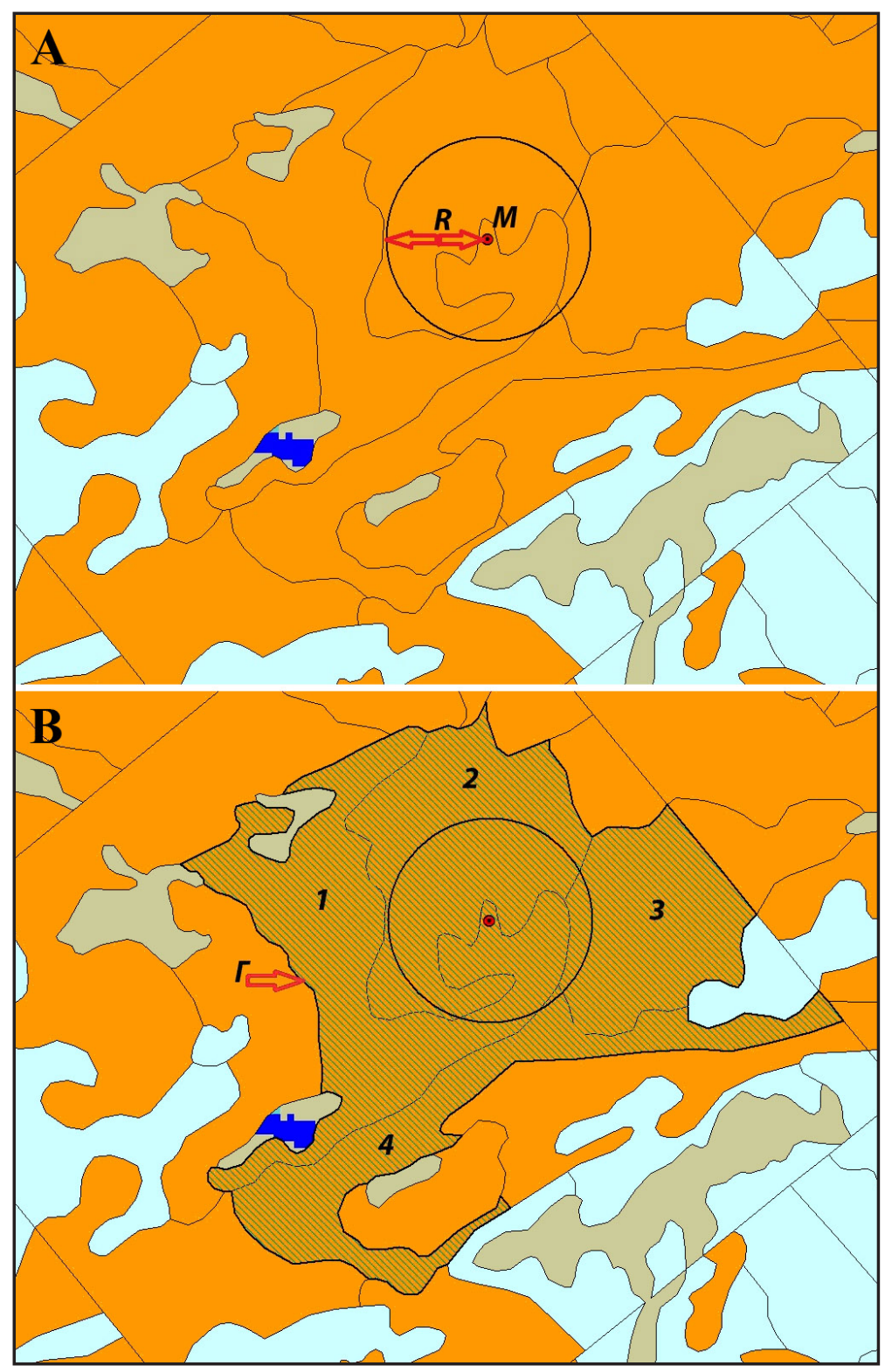

расположенных либо на дереве, либо (мля некоторых видов) на земле.

2. В ОЗУА АОлжны войти все выделы, которые пересекает радиус 150 м от точекмаркеров (рис. 9: А).

Граница ОЗУЛ проводится по границам этих вылелов. Но вылелы не "режутся" по радиусу в 150 м, а вылеляются по внешним границам вылелов, которые попадают в 150-ти метровую зону вокруг гнезда. Таким образом, в каждом случае плошадь ОЗУА всегАа разная и зависит от размеров лесных вылелов, попадаюших в радиус 150 м от маркеров (рис. 9: В).

3. Проект кажмого ОЗУА вкиючает: А) карту с нанесёнными границами ОЗУА и лесных вылелов, входящих в него; Б) таблицу с описанием вылелов, входяших в ОЗУЛ, и их плошахей.

$\triangle$ аная методика уже апробирована на примере ряла Аругих регионов, в частности в Республике Татарстан (Бекмансуров и $\Delta$ р., 2015).

$\Delta \wedge я$ территории заказников принцип выделения ОЗУЛ важен мля более крупного зонирования территории на эксплуатационную и зону особой охраны. По сути, зоны особой охраны Аолжны вкАючать самые ценные участки леса с максимальной концентрацией ОЗУЛ, территории между которыми также способствуют сохранению видов и могут вкиючать небольшие участки менее ценного леса, водоёмы и безлесные участки (луга, болота) мля формирования це^остности зоны. В этом случае границы зон особой охраны могут быть очерчены частично по границам лесных кварталов. Чем меньше булет расчленена зона особой охраны, тем это лучше мля сохранения реАКих виАов.

Такой подход был реализован в ЗавьяАовском заказнике в 2013 г. (рис. 10), гАе основой Аля вылеления зон особой охраны послужили точки-маркеры гнезАовых участков реАких виАов хишных птиц, Аополненные Аанными по произ-

Рис. 9. Методика вылеления ОЗУА: А - фрагмент плана месонасажцений с показанием точки-маркера $(M)$ и рахиусом $(R)$ в 150 м вокруг неё, B - границы ОЗУА (Г) с лесными выделами (1-4), входяшими в него.

Fig. 9. Methods of creating of the special protected forest zones : A - a fragment of the forest plan with a point-marker $(M)$ and radius $(R)$ of $150 m$ around it, $B$ - border of the special protected forest zone $(\Gamma)$ with forest clusters (1-4) included in it. 


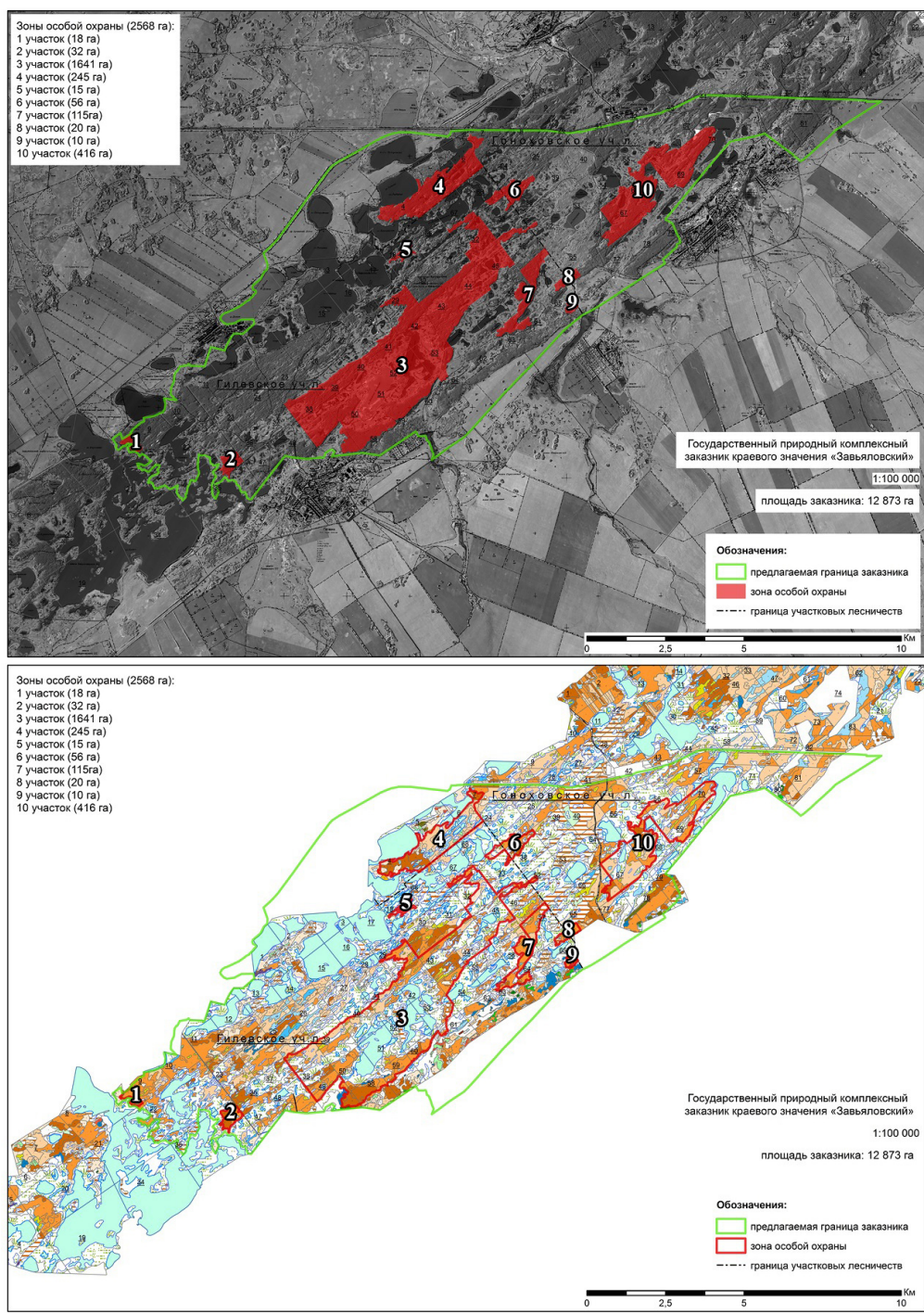

растанию редких видов растений. Такой же подход был принят при проектировании зон особой охраны в Касмалинском, Мамонтовском и Корниловском заказниках в 2015 г.
Рис. 10. Зоны особой охраны в Завьяловском заказнике: на космоснимке (вверху) и плане лесонасаждений (внизу).

Fig. 10. Special protection zones in the Zavyalovsky Nature Reserve: on satellite image (upper) and on a forest plan (bottom).

\section{Результаты выцеления зон особой ох- раны в трёх боровых заказниках Ал- тайского края}

Опираясь на описанный выше метод выделения зон особой охраны, мия трёх боровых заказников - Касмаминского

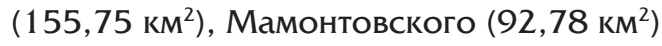

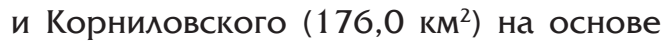
проведённых исследований построены схемы распределения гнездовых участков редких видов хишных птиц. Аия кажАого гнездового участка по планам лесонасаждений очерчены ОЗУА, исходя из минимальных параметров их выделения, специсических мия разных видов (см. табл. 2). Аалее ОЗУл были слиты в более крупные контуры проектируемых зон особой охраны заказника (Аалее 3003), исходя из наличия межАу ОЗУА биотопов, пригодных Аля гнездования редких видов, концентрации гнёзд обычных виАов хишных птиц, а также наличия колоний летучих мышей (Chiroptera) и мест произрастания редких растений. В итоге мля каждого заказника были спроектированы 3003.

В Касмалинском заказнике проектируемая площадь 3003 заняла 86,56 км², что составляет 55,57 \% от плошаяи заказника (рис. 11: А).

В Мамонтовском заказнике проектиру-
Опушка бора в Мамонтовском заказнике. Фото И. Карякина.

Edge of pine forest in the Mamontovsky Nature Reserve. Photo by I. Karyakin.

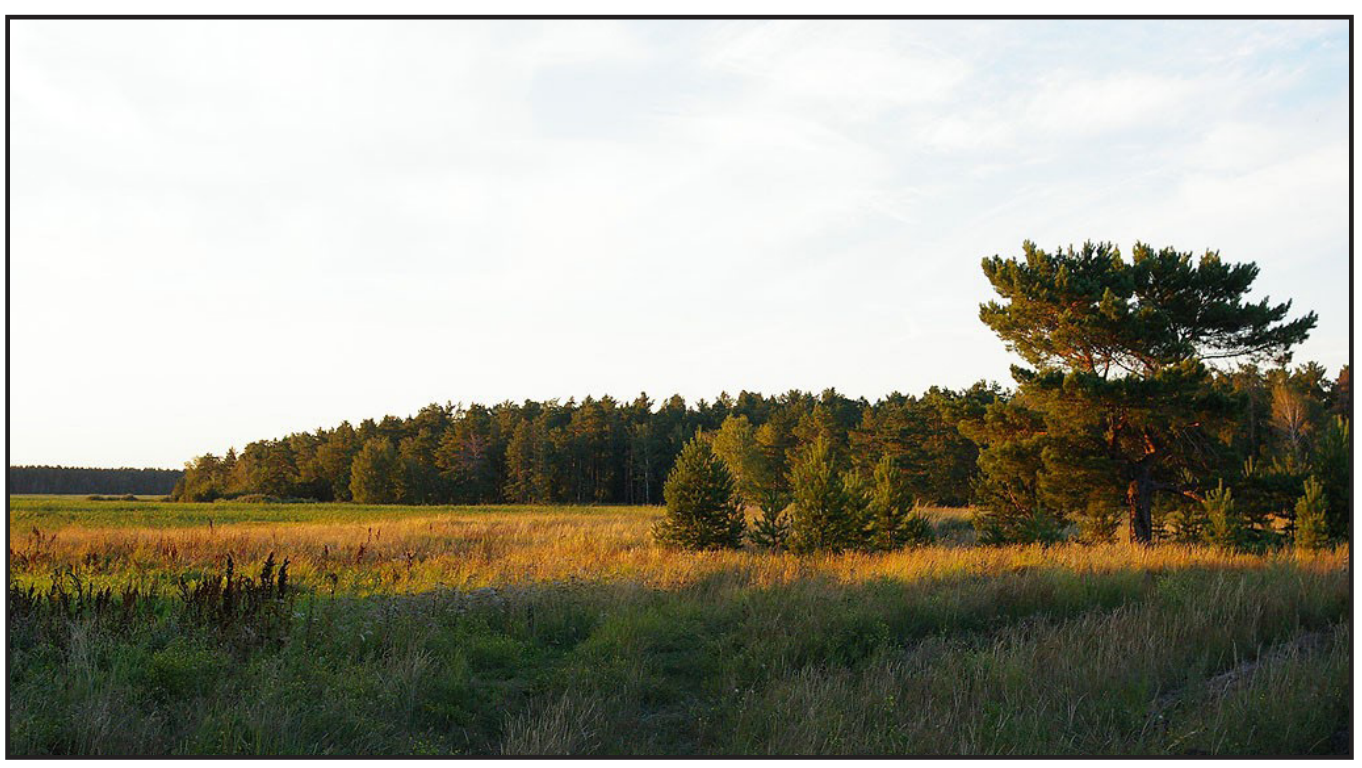



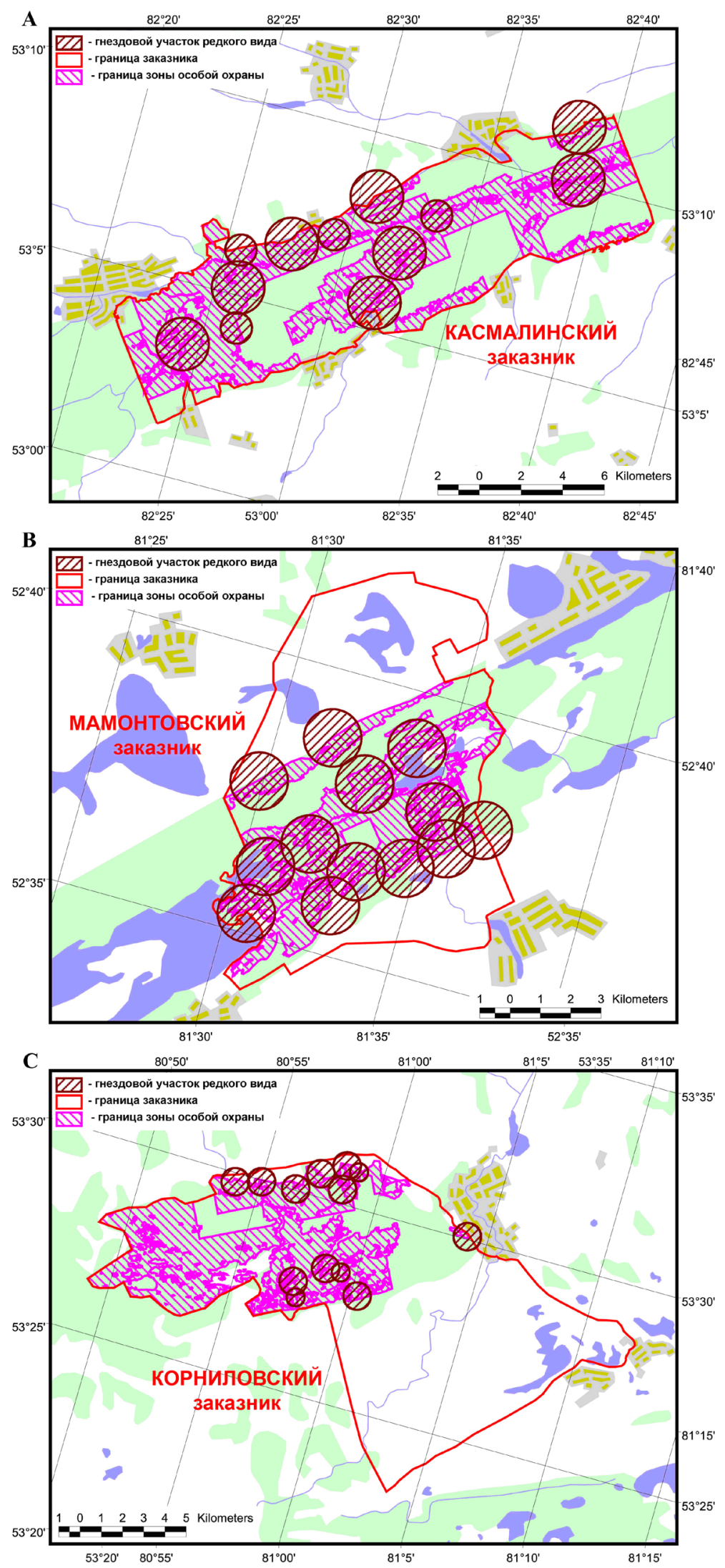

емая площаль 3003 заняла 23,15 км², что составляет 24,95 \% от площаци заказника (рис. 11: В).

В Корниловском заказнике проектируе-
Pис. 11. Проектируемые зоны особой охраны и гнездовые участки редких видов пернатых хишников в Касмачиснком (A), Мамонтовском (B) и Корниловском (C) заказниках.

Fig. 11. Projected special protection zones and breeding territories of rare raptors (circles) in the Kasmalisnky (A), Mamontovsky (B) and Kornilovsky (C) Nature Reserves.

мая плошадь 3003 заняла 51,04 км², что составляет $29,0 \%$ от плошаяи заказника (рис. 11: C).

Аалее с проектами 3003 будет вестись работа по их утвержмению в рамках обновлённых положений заказников уже силами Главного управления природных ресурсов и экологии Алтайского края. Остаётся только нацеется, что положения этих трёх заказников будут утверждены до того, как в них все гнездовые участки редких видов хишных птиц будут пройдены рубками.

Выявленные нарушения природоохранного законодательства при эксплуатации лесов в боровых заказниках Алтайского края

В ходе работы по мониторингу редких видов хишных птиц в боровых заказниках Алтайского края в 2015 г., выявлены многочисленные нарушения законодательства при осушествелнии рубок на территории Касмаминского, Мамонтовского, Завьяловского и Корниловского заказников, подтвержцено уничтожение нескольких гнёзд таких реАких виАов, как филин и большой подорлик, выявлены отводы в рубку на 2015-2016 гг. гнездовых участков "краснокнижных" видов птиц, причём участков, которые внесены в государственный каластр редких видов АИтайского края, в том числе и в уже утверж-

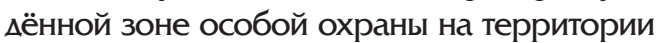
Завьяловского заказника.

Государственный природный комплексный заказник краевого значения “Касмачинский” создан мия сохранения природного комплекса экосистемы интразонамьного ленточного бора в кииматических условиях южной лесостепи; аккииматизации европейского бобра (Castor fiber) в пойме р. Касмала; сохранения мест естественного обитания животных и растений борового и водно-болотного комплексов; подмержания экологического баланса региона. Как следует из поможения о заказнике ${ }^{69}$, опубликованного 
на сайте Главного управления природных ресурсов и экологии Алтайского края, на территории заказника запрешается мюбая хозяйственная деятельность, приводящая к изменению состава и естественного состояния растительного и животного мира. Основные задачи заказника - сохранение биологического разнообразия, сохранение мест обитания редких и исчезаюших видов растений и животных, в том числе занесённых в Красную книгу Алтайского края, и т.п. Но что же на самом деле происходит в Касмаиинском заказнике и выполняет Аи он свои фуннции? Вероятно, не выполняет.

Касмалинский заказник по численности гнездяшихся редких пернатых хишников является одним из самых бедных среди боровых заказников края, и в первую очередь причиной этого являются рубки, которые, впрочем, Ао 2015 г. велись на территории заказника с меньшей интенсивностью. Тем не менее, за период с 2004 по 2013 гг. в заказнике рубками было уничтожено как минимум 2 гнезАовых участка больших подорликов и 2 гнездовых участка фрилинов. В 2013 г. Аобровольно выборочной рубкой в 24 кварале 33 вылела уничтожен гнездовой участок филина ${ }^{70}$. В 2015 г. в рубку отвемены участки леса, лежашие в проектируемой зоне особой охраны заказника в 34 квартале на гнездовой территории большого подорлика ${ }^{71}$, последний активный гнездовой участок фрилина в заказнике ${ }^{72}$, 73, 74, гнездовой участок орла-могильника в кв. $15^{75,76,77,78}$ и гнездовая территория большого подорлика в кв. 51 79, 80, 81, 82. В 2016 г. в рубку отведены гнездовой участок орла-могильника в кв. $31^{83}$, гнездовая территория большого подорлика в кв. 70 84, 85, 86. Таким образом, если эти рубки не удастся остановить, в Касмалинском заказнике в 2015-2016 гг. будут пройдены рубками все имеюшиеся участки орла-могильника и половина известных участков большого подорлика, и, весьма вероятно, что в ходе рубок будут уничтожены не только местообитания, но и сами гнёзда, так как на одном из участков орлов лесосечный столбик стоит в 150 м от жилого гнезда. - Вот таким образом под контролем Главного управления природных ресурсов и экологии А^тайского края на территории Касмаминского заказника происходит сохранение биологического разнообразия и мест обитания редких и исчезающих вилов растений и животных, в том числе занесённых в Красную книгу А^тайского края и РФ.

В этом году обследование Касмалинского заказника также осушествлялось в рамках грантового проекта Русского геограсического обшества "Ленточные боры Алтая - уникальное природное наследие России" специалистами ряла научных организаций Алтайского края, в том числе, Института водных и экологических проблем СО РАН и Тигирекского заповедника. Они, вероятно, также внесли свою лепту в познание того, какие редкие виды и гАе будут уничтожены в Касмаминском заказнике в ближайшее время.

Согласно инсрормации начальника отлела особо охраняемых природных территорий Главного управления природных ресурсов и экологии Алтайского края И.В. Аудина ${ }^{87}$, в текушем году буАет решаться вопрос о выделении зоны особой охраны в Кислухинском заказнике, который расположен недалеко от Барнаула, а результаты мониторинга Касмалинского заказника мягут в основу работы по зонированию в 2016 г., т.е. после того, как все ценные участки заказника будут вырублены. Возможно, не случайно лесозаготовитель ("Алтайлес") в Касмалинском заказнике активизировал рубки в 2015-2016 гг.

Весь Касмаминский заказник уже сейчас размечен лесосечными столбиками. При этом Ао сих пор ешё не известно, сколько гнездовых участков редких видов хишных птиц попадают в рубки на территории, которая не была обследована (это примерно 40 \% от плошади заказника). А помимо редких пернатых в заказнике обитает множество редких животных метучих мышей и насекомых, произрастает множество редких растений, местообитания которых тоже $А$ сих пор полностью не выявлены.
70 http://oopt.wildlifemonitoring.ru/\#object/o_id=31449

71 http://oopt.wildlifemonitoring.ru/\#object/o_id=31445

72 http://oopt.wildlifemonitoring.ru/\#object/o_id=31446

73 http://oopt.wildlifemonitoring.ru/\#object/o_id=31447

74 http://oopt.wildlifemonitoring.ru/\#object/o_id=31448

75 http://oopt.wildlifemonitoring.ru/\#object/o id=30689

76 http://oopt.wildlifemonitoring.ru/\#object/o_id=30690

77 http://oopt.wildlifemonitoring.ru/\#object/o_id=30691

78 http://oopt.wildlifemonitoring.ru/\#object/o_id=30692
79 http://oopt.wildlifemonitoring.ru/\#object/o_id=31435

so http://oopt.wildlifemonitoring.ru/\#object/o_id=31436

81 http://oopt.wildlifemonitoring.ru/\#object/o_id=31437

82 http://oopt.wildlifemonitoring.ru/\#object/o id=31438

83 http://oopt.wildlifemonitoring.ru/\#object/o_id=30694

84 http://oopt.wildlifemonitoring.ru/\#object/o_id=31439

85 http://oopt.wildlifemonitoring.ru/\#object/o_id=31440

86 http://oopt.wildlifemonitoring.ru/\#object/o_id=31441

87 http://altaipriroda.ru/news/?id=4112 
Государственный природный компмексный заказник краевого значения "Мамонтовский" СозАан А^я сохранения экосистем Касмалинского ленточного бора с системой озёр; мест естественного обитания ^ося, косули, белки, зайца, мисицы, колонка, лебеАя, речных и нырковых уток и Аругих животных; подмержания экологического баланса региона; воспроизводства комплекса животных и растений леса и лесной озёрной системы. Как следует из положения о заказнике ${ }^{88}$, опубликованного на сайте Главного управления природных ресурсов и экологии Алтайского края, на территории заказника запрешается рубка леса, кроме рубок согласно материалам лесоустройства, прошедшим государственную экологическую экспертизу, рекомендациям лесопатологического обследования, проведённого в строгом соответствии с Санитарными правилами в лесах Российской Федерации, а также мия прокламки кинейных объектов и Аругих государственных нужА в установленном законодательством порядке. В основные задачи заказника входит сохранение биологического разнообразия; охрана лесных и водноболотных угодий как мест естественного обитания животных и растений; сохранение водоохранных лесов; обеспечение режима покоя мия животных и т.п.

Ешё в 2012 г. Сибэкоцентром было

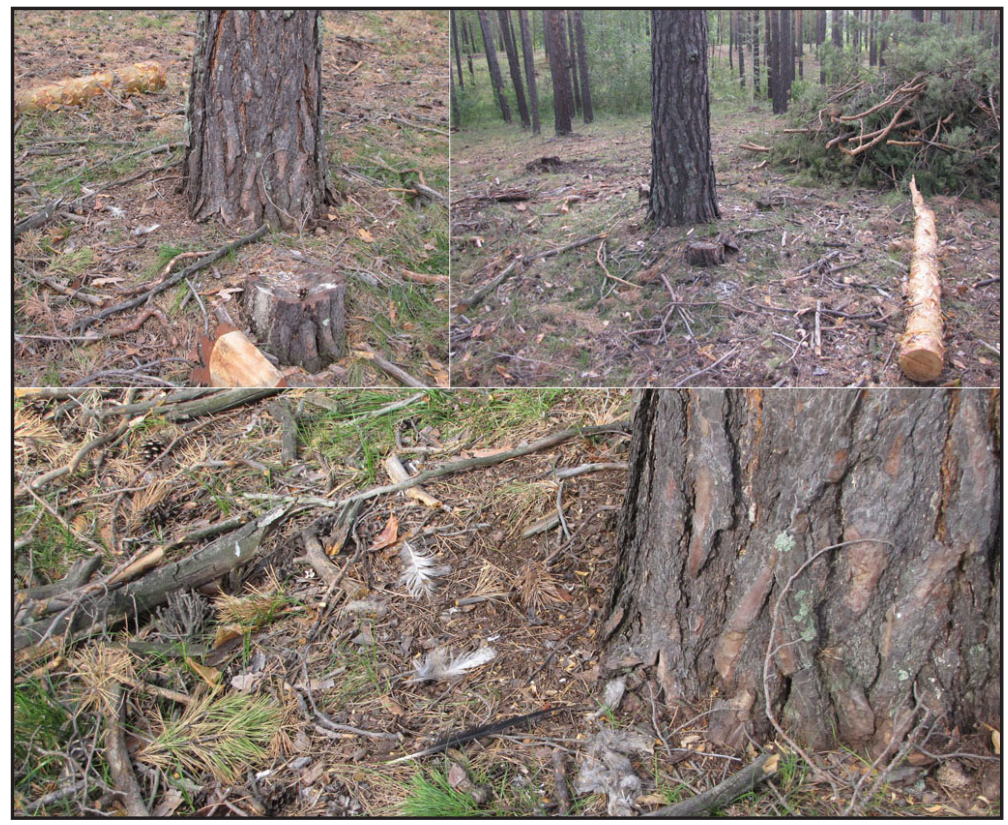

установлено, как в Мамонтовском заказнике сохраняют места естественного обитания животных и растений, водоохранные леса и обеспечивают режим покоя мия животных. ТогАа выявлено полное уничтожение местообитания большого

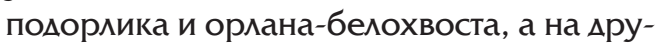

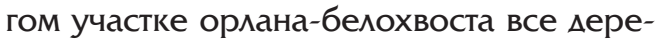
вья вокруг гнездового были вырублены, после чего гнезАо на одиноко стояшем $\Delta е-$ реве среди вырубки, обдуваемое всеми ветрами и заметное издалека, естественно, было брошено птицами. Выявленные нарушения легли в основу обрашения обшественников в прокуратуру ${ }^{\boldsymbol{8 9}}$, однако по Аанному факту не было возбужлено даже Аела об амминистративном правонарушении. В марте 2013 г. на сессии Мамонтовского районного собрания Аепутатов представители трех районов обсудили проблему массовой вырубки леса в ленточных борах Алтайского края и подготовили Аостаточно прогрессивные решения по этой проблеме, однако подготовка результируюших Аокументов была саботирована главами района и районной ахминистрации ${ }^{90}$.

После проведённых в 2011-2013 гг. масштабных рубок в Мамонтовском заказнике осталось очень мало вылелов ненарушенного леса, поэтому последние 2 года рубки ведутся точечно, но, тем не менее, и в 2015 г. лесорубам удалось полностью пройти рубками гнездовой участок филина в 45 кв. заказника ${ }^{91,92}$. Птенцу из выводка удалось выжить, и при нашем посешении участка он в сопровождении взрослых птиц активно вокализировая на краю вырубки, но определённо, что фрилины больше здесь не будут размножаться.

По соседству с Мамонтовским заказником варварские рубки на гнездовых участках редких видов идут в таких же

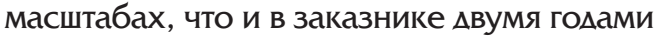
раньше. 3Аесь в 2015 г. пройден рубками

Гнездо филина в Мамонтовском заказнике, лес вокруг которого вырублен, причём в водоохранной зоне - прямо на берегу водоёма. Фото И. Карякина.

The cut down forest surrounded the nest of the Eagle Owl in the water protection zone in the Mamontovsky Nature Reserve. Photos by I. Karyakin.

s8 http://altaipriroda.ru/directions/prirodnye_resursy/oopt/zakazniki/mamontovskij_zakaznik/

89 http://rrrcn.ru/wp-content/uploads/2015/08/Act-Mamontovsky-2012.pdf

90 http://ecodelo.org/ekoproekty/ustoichivoe_lesopolzovanie/20648-raionnye_deputaty_obespokoeny_masshtabami_rubok_v_lentoc

91 http://oopt.wildlifemonitoring.ru/\#object/o_id=31872

92 http://oopt.wildlifemonitoring.ru/\#object/o_id=31873 
гнездовой участок большого подорлика, что привело к гибели киамки 93 , причём восстановление участка маловероятно, так как рубками пройдены все выделы старого леса на берегу озера, гле бы подорлик мог успешно размножаться, рубки проведены вокруг всех амьтернативных гнёзд пары, что делает невозможным размножение орлов на них ${ }^{94,95}$. Успешное размножение подорлика на этом участке последний раз отмечено в 2011 г. Также в 2015 г. близ границы Мамонтовского заказника летом проведена рубка на гнездовом участке орлана-белохвоста ${ }^{96}$. По счастливой случайности слёткам удалось покинуть гнез$\Delta о$ мо начала рубок, однако судьба гнезда остаётся поА вопросом. Возможно, птицы бросят участок.

Государственный природный комплексный заказник краевого значения “Завьяловский» создан мия сохранения природного комплекса южной окраинной части Кулундинского ленточного бора, расположенного в умеренно-засушливой степной зоне; сохранения мест естественного обитания лося (Alces alces), косули (Capreolus pygargus), ондатры (Ondatra zibethicus), барсука (Meles meles), водоплаваюших и лесных птиц; подмержания экологического баланса региона; воспроизводства белки (Sciurus vulgaris), косули, барсука, ^ося, мисицы (Vulpes vulpes), тетерева (Lyrurus tetrix) и охраны местообитаний редких орлана-белохвоста и большой белой цапли.

Совсем недавно Завьяловский заказник был еАинственной в мире территорией, гле сохранялась гнездовая группировка большого подорлика, по численности, превышаюшая популяцию всей зарубежной Европы (Польши и Прибалтики), и орлы здесь гнездились с плотностью, максимальной ммя вида - 1-1,5 км между соседями. Но стараниями сначала ООО

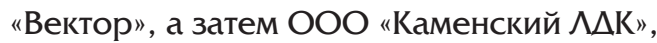
входяшего в хольинг "А^тайлес" более половины местообитаний большого подорлика в заказнике были уничтожены рубками. По выявленным фрактам уничтожения гнёзА большого подорлика и филина в Завьяловском заказнике и ряле Аругих заказников Алтайского края в 2012 г. Сибэкоцентром совместно с Геблеровским экологическим обшеством было подготовлено обрашение ${ }^{97}$ в прокуратуру. В ответ на обрашение обшественности с целью сохранения гнёзд большого подорлика в Завьяловском заказнике исполнительному директору ООО «Вектор" С.И. Беспалову природоохранным прокурором объявлено предостережение о недопустимости нарушения закона ${ }^{98}$. ОАнако С.И. Беспалов требование прокуратуры проигнорировая и один из гнездовых участков подорликов был пройден рубками, а гнезАо брошено птицами. История об этом описана на сайте Российской сети изучения и охраны пернатых хишников ${ }^{99}$. $\Delta$ алее было судебное разбирательство, в ходе которого уже правоприемник ООО “Вектор" - ООО "Каменский $\mathcal{} \Delta K$ ” был уличён в нарушении природоохранного законодательства в ходе рубок и уничтожении гнёзд большого подорлика и филина в Завьяловском заказнике ${ }^{100}$.

Несмотря на постоянное Аавление со стороны обшественности и прокуратуры,
Рубка летом 2015 г. в Завьяловском заказни ке в 36 кв. Гилёвского ^-ва на гриве ближайшей к кромке озера в пределах гнездовой территории большого подорлика.

Фото И. Карякина.

Logging within the boundaries of the breeding territory of the Greater Spotted Eagle in the Zavyalovsky Nature Reserve, summer of 2015 Photo by I. Karyakin.

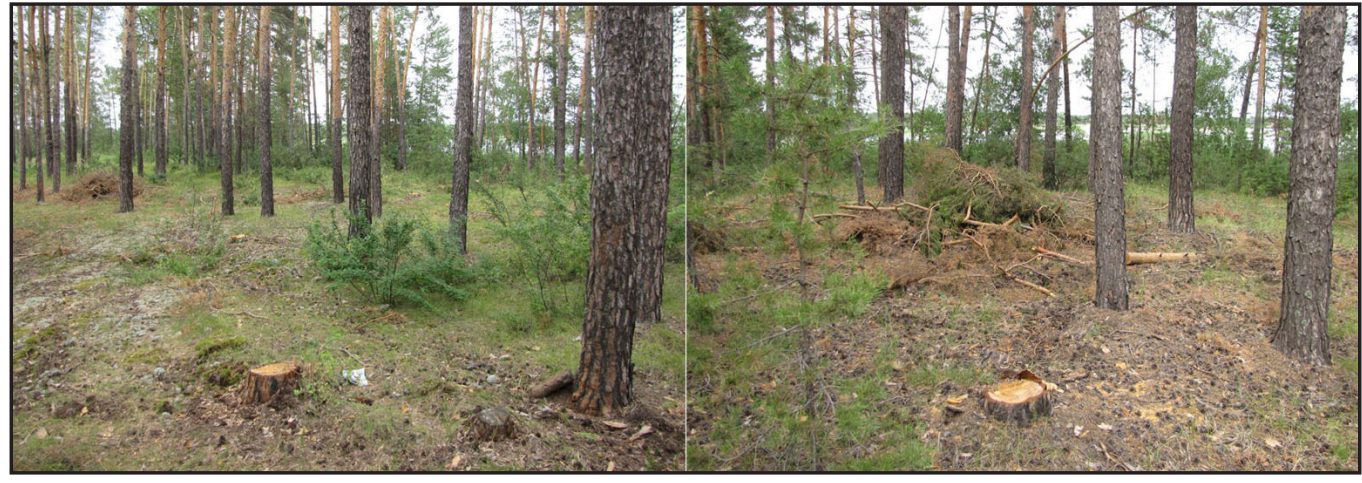

93 http://oopt.wildlifemonitoring.ru/\#object/o_id=31991

94 http://oopt.wildlifemonitoring.ru/\#object/o_id=31989

95 http://oopt.wildlifemonitoring.ru/\#object/o_id=31990

96 http://oopt.wildlifemonitoring.ru/\#object/o_id=31870

97 http://rrrcn.ru/wp-content/uploads/2013/01/pril2_zayav_prok.pdf

98 http://rrrcn.ru/wp-content/uploads/2013/01/pril7_otvet_prok.pdf

99 http://rrrcn.ru/archives/19770

100 http://rrrcn.ru/ru/archives/21355 
лесорубы не оставили в покое Завьяловский заказник, и филины и подорлики так и не получили возможность спокойно размножаться. В 2014 г. проведены рубки на очередном гнездовом участке большого подорлика и птицы бросили участок ${ }^{101}$. В это время мия территории Завьяловского заказника были разработаны зоны особой охраны, проект которых согласован с Управлением лесами, а лесопользователи уведомиены о запрете рубок в местообитаниях реАких видов. Но в 2015 г. при проведении мониторинга гнездовых участков хишных птиц группа Российской сети изучения и охраны пернатых хищников обнаружила лесосечные столбики именно в зоне особой охраны на гнезАовом участке большого подорлика. Этот участок уже Аважды был пройден рубками за период с 2004 по 2013 гг. и каждый раз орлы были вынуждены бросать обрубленное со всех сторон гнездо и уходить Ааише от побережья озера. В итоге они забрались в последний сохранившийся на участке вылел ненарушенного рубками леса, который и был отведён в рубку на 2015 г. ${ }^{102,103,104}$. На обрашение Геблеровского экологического обшества в Главное управление природных ресурсов и экологии Алтайского края по факту обнаружения лесосечных столбиков в зоне особой охраны Завьяловского заказника на гнезАовом участке подорлика был получен ответ, что лесосечные столбики расставлены ошибочно ${ }^{105}$.

Также в 2015 г. проведены рубки на гнездовой территории подорликов вне спроектированной охранной зоны в Завьяловском заказнике, но в водоохранной полосе, которая в заказнике и без всяких охранных зон Аолжна сохраняться ${ }^{106}$. В Аанном случае гнездо подорликов не пострахало, однако были вырублены деревья с его постоянными присадами и как это скажется на Ааиьнейшей судьбе участка пока неясно.

Государственный природный компмексный заказник краевого значения “Корнимовский" созАан мия сохранения природных экосистем соснового леса островного характера среди ландшасрта южной лесостепи и водно-болотных угоАий и урочищ; восстановления численности норки, ондатры и лося; подмержания экологического баланса региона; воспроизводства и сохранения водно-бо^отного и лесного комплексов животных. Основными задачами заказника являются сохранение биологического разнообразия, вкһючая поццержание естественного водного режима в системе озёр правой части бассейна р. Кулунда, охрану местообитаний реАких и находяшихся поА угрозой исчезновения виАов животных, улучшение условий обитания животных путём проведения биотехнических мероприятий и т.А.

Как следует из положения о заказнике $^{107}$, опубликованного на сайте Главного управления природных ресурсов и экологии Алтайского края, на территории заказника запрешается кюбая хозяйственная деятельность, приводящая к изменению состава и естественного состояния растительного и животного мира. Из большого списка того, что на территории заказника допускается, рубки не значатся вовсе. Тем не менее, заказник АОвольно интенсивно рубится, особенно в последние 2 года. На территории заказника гнездилась последняя известная в ленточных борах пара беркутов, к участку которой в 2015 г. рубки подошли со всех сторон (может по этой причине беркуты покинули участок - теперь их постройку занял большой подорлик, гнезАившийся в вылеле, который был пройден рубками зимой 2014/2015 г.).

На 2015 г. рубки назначены сразу же на Авух гнездовых участках больших подорАиков ${ }^{108,} 109$ и на одном гнездовом участке подорлика рубка планируется в 2016 г. ${ }^{110}$. Стоит отметить, что Корниловский заказник - это второй в крае заказник после Завьяловского, на территории которого сохраняется высокая плотность гнездования больших подорликов. Также здесь известны гнёзда орлана-белохвоста, филина и бородатой неясыти, что делает территорию заказника очень ценной мля сохра-

\footnotetext{
101 http://oopt.wildlifemonitoring.ru/\#object/o_id=27153

102 http://oopt.wildlifemonitoring.ru/\#object/o_id=32045

103 http://oopt.wildlifemonitoring.ru/\#object/o_id=32046

104 http://oopt.wildlifemonitoring.ru/\#object/o_id=32047

105 http://rrrcn.ru/forum/viewtopic.php? $f=19 \& t=152 \# p 2852$

106 http://oopt.wildlifemonitoring.ru/\#object/o_id=32040

107 http://altaipriroda.ru/directions/prirodnye_resursy/oopt/zakazniki/kornilovskij_zakaznik/

108 http://oopt.wildlifemonitoring.ru/\#object/o_id=31875

109 http://oopt.wildlifemonitoring.ru/\#object/o_id=31877

110 http://oopt.wildlifemonitoring.ru/\#object/o_id=31876
} 


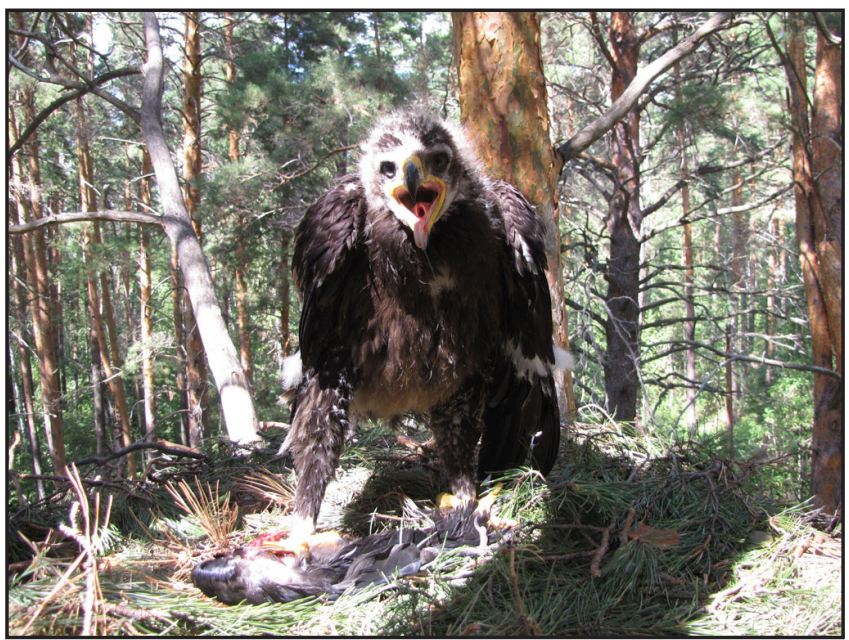

Птенец большого поАорлика в гнезде. Фото И. Карякина.

Nestling of the Greater Spotted Eagle in the nest.

Photo by I. Karyakin. нения редких видов пернатых хишников Аитайского края. Однако как на практике охраняются эти виды в заказнике видно Ааже из этого обзора по небольшому фрагментарному исследованию лишь $20 \%$ территории заказника в 2015 г.

\section{Закиючение}

Состояние боровых популяций редких вилов хишных птиц в Аитайском крае показывает негативное влияние рубок, ведушихся в ленточных борах, на большинство из них. Аия беркута и срилина можно говорить о том, что рубки уже привели к $А$ грахации их популяций, и мля беркута это уже закончилось фатально.

Разработанные критерии вылеления ОЗУА позволят сохранить редкие виды хишных птиц в эксплуатируемых борах Алтайского края без серьёзных потерь мля лесозаготовителей. Поэтому практику выделения ОЗУА необходимо расширять на все эксплуатационные леса и грамотно Аоносить Ао лесопользователей плюсы этой деятельности. В перспективе все гнездовые участки редких видов хищных птиц, внесённые в государственный ка-
Felled the nest Photo by I. Karyakin. мастр, Аолжны быть осрормлены в качестве ОЗУЛ.

Вылеление ОЗУА в эксплуатационных лесах может снизить напряжённость в отношениях межАу лесозаготовителями и обшественностью, если лесозаготовители поймут, что цель экологов не прекратить рубки и лишить лесозаготовительные компании прибыли в угоду интересам третьих миц, а сохранить редкие виды и наиболее ценные лесные территории, при продолжаюшейся эксплуатации лесов.

Зоны особой охраны в заказниках Аолжны быть утверждены в кратчайшие сроки. Пока предприятия холдинга "Алтайлес" не собираются останавливать рубки в заказниках, а значит, природоохранная ценность заказников снижается с кажАым годом.

Из приведённого обзора нарушений природоохранного законодательства при эксплуатации боровых лент, можно слелать вывод, что в ближайшее время лесопользователи будут стараться валить лес, несмотря на нарушение ими законодательства РФ. При полной недееспособности государственных органов нацзора в ссрере охраны природы и природопользования в Алтайском крае, попытки вырубать даже особо охраняемые территории будут продолжаться лесозаготовителями. На фоне этого мишь регулярные обшественные инспекции смогут сохранить от уничтожения ценные лесные территории. Вылеление ОЗУА на лесных территориях вне ООПТ и 3003 не панацея, а ^ишь некий шаг в сторону большей зашишенности территории от лесозаготовителей и осложнения им незаконного освоения лесов. Поэтому все вылеленные ОЗУА и 3003 Аолжны контролироваться обшественностью в первую очередь и на регулярной основе.

\section{Благодарности}

Авторы выражают благодарность Александру Милежику и Виктору Матафонову за помошь в проведении экспеАиций в боровых заказниках Алтайского края, Сергею Важову и Роману Бахтину за предоставленную неопубликованную информацию о локализации точек встреч хищных птиц в борах, Алексанмру Шуру за помошь в подборе картограсических материалов и Алексею Грибкову за содействие в подготовке обрашений в госорганы и прокуратуру по фактам незаконных рубок в заказниках Алтайского края. 


\section{Литература}

Арамильев В.В., Крестов П.В., Скворцов В.Э., Сурмач С.Г., Верхолат В.П., Шиотгауэр С.А., Крюкова М.В., Беляев Е.А., Ликсакова Б.Н., Соколов С.А., Скороделов А.С., Аинков И.В., Аунишенко Ю.М., Аиексеенко А.Ю., Грек В.С., Морин В.А., Нечаев А.А., Кобяков К.Н. Методические указания по вылелению особо зашитных участков леса в местах распространения и обитания редких, охраняемых и ценных промысловых видов животных и растений юга Аамьнего Востока. Хабаровск, 2010. 50 с. [Aramil'ev V.V., Krestov P.V., Skvortsov V.E., Surmach S.G., Verholat V.P., Shlotgauer S.D., Kryukova M.V., Belyaev E.A., Liksakova B.N., Sokolov S.A., Skorodelov A.S., Linkov I.V., Dunishenko Yu.M., Alekseenko A.Yu., Greek V.S., Morin V.A., Nechaev A.A., Kobyakov K.N. Guidelines on the allocation of specially protected forest areas in the field of distribution and habitats of rare, protected and valuable commercial species of animals and plants in the south of the Far East. Khabarovsk, 2010: 1-50. (in Russian)].

Бемансуров Р.Х., Карякин И.В., Томаева И.Ф. О создании особо зашитных участков месов в местах гнездования редких видов хишных птиц в Республике Татарстан. - Охрана природной среды и эколого-биологическое образование: сборник материалов международной научно-практической конференции, г. Елабуга, 25-26 ноября 2015 года / под ред. В.В. Леонтьева. - Елабуга, 2015. С. 190-194 [Bekmansurov R.H., Karyakin I.V., Tomaeva I.F. About the establishment of specially protected forest areas on the breeding territories of rare species of birds of prey in the Republic of Tatarstan. - Protection of the environment and ecological-biological education: proceedings of the International Scientific-Practical Conference, Elabuga, 25-26 November 2015 / Ed. V.V. Leontyev. - Elabuga, 2015: 190-194]. URL: http://rrrcn.ru/wp-content/uploads/2015/12/ Bekmansurov-etal-OZUL.pdf Аата обрашения: 01.12.2015.

Важов С.В. Могильник в Республике Алтай и Алтайском крае, Россия. - Пернатые хищники и их охрана. 2010. № 20. С. 146-157 [Vazhov S.V. The Imperial Eagle in the Republic of Altai and Altai Kray, Russia. - Raptors Conservation. 2010. 20: 146-157]. URL: http:// rrrcn.ru/ru/archives/19262 Аата обрашения: 28.08.2015.

Важов С.В., Рыбаиьченко А.В. Результаты мониторинга некоторых гнездовых участков фиилина в Аитайском крае в 2012 г., Россия. Пернатые хишники и их охрана. 2013. № 26. C. 109-115 [Vazhov S.V., Rybalchenko D.V. Monitoring Results for Some Breeding Territories of the Eagle Owl in the Altai Kray in 2012, Russia. Raptors Conservation. 2013. 26: 109-115]. URL: http://rrrcn.ru/ru/archives/19597 Аата обрашения: 28.08.2015.
Витер С.Г. "Гнездовой консерватизм" (верность месту), лесное хозяйство и стратегия охраны хишных птиц в Украине. - Пернатые хищники и их охрана. 2014. № 29. С. 39-51. doi 10.19074/1814-8654-2014-29-39-51 [Viter S.G. A Site Fidelity, Forestry and Raptor Conservation in Ukraine. - Raptors Conservation. 2014. 29: 39-51. doi: 10.19074/1814-8654-2014-29-3951.]. URL: http://rrrcn.ru/ru/archives/25757 Аата обрашения: 28.08.2015.

Грибков А. Заказники - под топор? - Российская сеть изучения и охраны пернатых хишников. 2014 [Gribkov A. Nature Reserves - under axe? - Russian Raptor Research and Conservation Network. 2014]. URL: http://rrrcn.ru/ru/archives/19850 Аата обрашения: 28.08.2015.

Карякин И.В. Пернатые хишники (методические рекомендации по изучению соколообразных и совообразных). Нижний Новгород, 2004. 351 c. [Karyakin I.V. Raptors (manuals on surveys of birds of prey and owls). Nizhniy Novgorod: Publishing House "Povolzhie", 2004 1-351 (in Russian)]. URL: http://rrrcn.ru/ru/archives/11151 Аата обрашения: 28.08.2015.

Карякин И.В. Результаты мониторинга попумяции филина в ленточных борах Алтайского края, Россия. - Пернатые хишники и их охрана. 2014. № 29. С. 77-92. doi: 10.19074/18148654-2014-29-77-92 [Karyakin I.V. Monitoring Results of the Eagle Owl Population in the Stripshaped Pine Forests in the Altai Kray, Russia. - Raptors Conservation. 2014. 29: 77-92. doi: 10.19074/1814-8654-2014-29-77-92]. URL: http://rrrcn.ru/ru/archives/25722 Аата обрашения: 28.08.2015.

Карякин И.В., Николенко Э.Г., Барашкова А.Н., Смелянский И.Э., Коновачов А.И., Грабовский М.А., Важов С.В., Бекмансуров Р.Х. Беркут в Алтае-Саянском регионе, Россия. Пернатые хищники и их охрана. 2010. № 18 . C. 82-152 [Karyakin I.V., Nikolenko E.G., Barashkova A.N., Smelansky I.E., Konovalov L.I., Grabovskiy M.A., Vazhov S.V., Bekmansurov R.H. Golden Eagle in the Altai-Sayan Region, Russia. Raptors Conservation. 2010. 18: 82-152]. URL: http://rrrcn.ru/ru/archives/19384 Аата обрашения: 28.08.2015.

Карякин И.В., Николенко Э.Г., Шнайдер Е.П. Результаты мониторинга популяции балобана в Алтае-Саянском регионе в 2014 году, Россия. - Пернатые хишники и их охрана. 2014. № 29. C. 58-76. doi: 10.19074/1814-8654-201429-58-76 [Karyakin I.V., Nikolenko E.G., Shnayder E.P. Results of Monitoring of the Saker Falcon Population in the Altai-Sayan Region in 2014, Russia. - Raptors Conservation. 2014. 29: 5876. doi: 10.19074/1814-8654-2014-29-58-76]. URL: http://rrrcn.ru/archives/25729 Аата обрашения: 28.08.2015.

Карякин И.В., Смелянский И.Э., Бакка С.В., Грабовский М.А., Рыбенко А.В., Егорова А.В. Крупные пернатые хишники Алтайского края. - Пернатые хишники и их охрана. 2005. № 3. 
C. 28-51 [Karyakin I.V., Smelansky I.E., Bakka S.V., Grabovsky M.A., Rybenko A.V., Egorova A.V. The Raptors in the Altai Kray. - Raptors Conservation. 2005. 3: 28-51]. URL: http://docs. sibecocenter.ru/programs/raptors/RC03/raptors_conservation_2005_3_pages_28_51.pdf Аата обрашения: 28.08.2015.

Кобяков К., Яницкая T. Разработка параметров особо зашитных участков леса в рамках концепции АВПЦ на юге Аамьнего Востока России. - Устойчивое лесопользование. 2007. № 1 (13). C. 24-28 [Kobyakov K., Yanitskaya T. Development parameters specially protected forest areas under the concept of HCVF in the south of the Russian Far East. - Sustainable forest management. 2007. 1 (13): 24-28]. URL: http://www.wwf.ru/data/publ_period/forest_ mag13/05.pdf Аата обрашения: 28.08.2015.

Методика исчисления размера вреда, причинённого объектам животного мира, занесённым в Красную книгу Российской Федерации, а также иным объектам животного мира, не относяшимся к объектам охоты и рыболовства и среде их обитания, утвержденной приказом МПР России от 28 апреля 2008 г. № 107. [The Methodology for Estimating the Level of Damage Caused to Species Listed in the Red Data Book of Russian Federation, as Well as to Non-Game Species and their Habitats (Approved by decree of the Ministry of Natural Resources of Russia from 28.04.2008 № 107) (in Russian)].

Николенко Э.Г. Изнанка "Стратегии развития лесной отрасли Алтайского края на период $\Delta$ о 2025 года". - Пернатые хишники и их охрана. 2014. № 29. C. 10-17. doi: 10.19074/18148654-2014-29-10-17 [Nikolenko E.G. The Reverse Side of the "Strategy of the Altai Kray Forest Industry for the Period up to the Year 2025". - Raptors Conservation. 2014. 29: 10-17. doi: 10.19074/1814-8654-2014-29-10-17]. URL: http://rrrcn.ru/ru/archives/25765 $\Delta$ ата обрашения: 28.08.2015.

Николенко Э.Г., Карякин И.В., Грибков А.В. Проблемы охраны лесных местообитаний редких видов в региональных заказниках Алтайского края постепенно решаются. - Пернатые хишники и их охрана. 2012. № 25. С. 28-33 [Nikolenko E.G., Karyakin I.V., Gribkov A.V. Problems of Protection of Forest Habitats of Rare Species in Regional Reserves of the Altai Kray are Resolving. - Raptors Conservation. 2012. 25: 28-33]. URL: http://rrrcn.ru/archives/19090 Аата обрашения: 28.08.2015.

Николенко Э.Г., Карякин И.В., Грибков А.В. Проблемы охраны месных местообитаний редких вицов хишных птиц в региональных заказниках Аитайского края. - Охрана птиц в России: проблемы и перспективы. Мат-лы Всероссийской научно-практической конференции с международным участием, посвяшенной 20-летию Союза охраны птиц России (Москва, 7-8 февраля 2013 г.) / Отв. реА.
Г.С. Ажамирзоев. Москва, Махачкама, 2013. C. 102-105. [Nikolenko E.G., Karyakin I.V., Gribkov A.V. Problems of Protection of Forest Habitats of Rare Species of Raptors in Regional Reserves of the Altai Kray are Resolving. - Problems and outlook of bird conservation in Russia. Proceedings of the All-Russian Conference, dedicated to the $20^{\text {th }}$ anniversary of Russian Bird Conservation Union (Moscow, 7-8 February 2013) / Ex. Editor G.S. Dzhamirzoev. Moscow - Makhachkala, 2013: 102-105. (in Russian)]. URL: http://rrrcn.ru/ru/archives/19662 Аата обрашения: 28.08.2015.

Равкин Ю.С., Карякин И.В., Николенко Э.Г., Важов С.В., Бахтин Р.Ф. Сбор и анаииз инсормации о местах обитания и гнездования видов, занесенных в Красную книгу А^тайского края: беркут, степной орёл, орёл-могильник, орланбелохвост, большой подорлик, сокол-бамобан, филин, бородатая неясыть; подготовка банка Аанных. - Отчет о выполнении работ. Новосибирск, 2013. 23 с. [Ravkin Yu.S., Karyakin I.V., Nikolenko E.G., Vazhov S.V., Bachtin R.F. The collection and analysis of information on habitats and nesting species listed in the Red Book of the Altai Kray: Golden Eagle, Steppe Eagle, Imperial Eagle, White-Tailed Eagle, Greater Spotted Eagle, Saker Falcon, Eagle Owl, Great Gray Owl; creation of a data bank. - Report on work. Novosibirsk, 2013: 1-23. (in Russian)]. URL: http:// rrrcn.ru/wp-content/uploads/2013/12/RepBD_2013.pdf Аата обрашения: 28.08.2015.

Рыжков В. За вырубкой уникальных менточных боров может стоять глава Аитайского края Александр Карлин и чиновники управляюшей регионом команды. - Преступная Россия. 2013. [Ryzhkov V. The head of the Altai Region Alexander Karlin and officials of governing team might be behind the felling of unique strip-shaped pine forests. - Criminal Russia. 2013. (in Russian)]. URL: http://crimerussia.ru/ corruption/64484-za-vyrubkoj-unikalnykh-lentochnykh-borov-mozhet-stoyat-glava-altajskogo-kraya-aleksandr-karlin-i-chinovniki-upravlyayushchej-regionom-komandy $\triangle$ ата обрашения: 28.08.2015.

Смелянский И.Э. Алтайский край - будушее оАного из крупнейших российских очагов разнообразия пернатых хишников зависит от природоохранных мер. - Пернатые хишники и их охрана. 2005. № 3. C. 18-27. [Smelansky I.E. Altai Kray: the future of the largest raptorial diversity hotspots depends on urgent conservation measures. - Raptors Conservation. 2005. 3: 1827]. URL: http://docs.sibecocenter.ru/programs/ raptors/RC03/raptors_conservation_2005_3_ pages_18_27.pdf Аата обрашения: 28.08.2015.

Slaght J.C., Surmach S.G. Blakiston's Fishowl Bubo blakistoni and logging: Applying resource selection information to endangered species conservation in Russia. - Bird Conservation International. 2015: 1-11. doi:10.1017/ S0959270915000076. 